\title{
The production and turnover of extramatrical mycelium of ectomycorrhizal fungi in forest soils: role in carbon cycling
}

\author{
A. Ekblad • H. Wallander • D. L. Godbold • \\ C. Cruz • D. Johnson • P. Baldrian • R. G. Björk • \\ D. Epron • B. Kieliszewska-Rokicka $\cdot$ R. Kjøller • \\ H. Kraigher • E. Matzner $\cdot$ J. Neumann • C. Plassard
}

Received: 22 November 2012 / Accepted: 31 January 2013 / Published online: 26 February 2013

(C) The Author(s) 2013. This article is published with open access at Springerlink.com

\begin{abstract}
There is growing evidence of the importance of extramatrical mycelium (EMM) of mycorrhizal fungi in carbon (C) cycling in ecosystems. However, our understanding has until recently been mainly based on laboratory experiments, and
\end{abstract}

Responsible Editor: Philippe Hinsinger.

A. Ekblad $(\bowtie) \cdot$ R. G. Björk

School of Science \& Technology, Örebro University,

70182 Örebro, Sweden

e-mail: alf.ekblad@oru.se

H. Wallander

Department of Biology, Microbial Ecology Group,

Ecology Building, Lund University, 22362 Lund, Sweden

D. L. Godbold

Institute of Forest Ecology, Universität für Bodenkultur,

1190 Vienna, Austria

C. Cruz

Plant Biology, University of Lisbon, Lisbon, Portugal

D. Johnson

Institute of Biological and Environmental Sciences,

University of Aberdeen, Cruickshank Building,

St Machar Drive, Aberdeen AB24 3UU, UK

\section{P. Baldrian}

Laboratory of Environmental Microbiology,

Institute of Microbiology ASCR, 14220 Praha, Czech Republic

R. G. Björk

Department of Earth Sciences, University of Gothenburg,

P.O. Box 460, 40530 Gothenburg, Sweden knowledge of such basic parameters as variations in mycelial production, standing biomass and turnover as well as the regulatory mechanisms behind such variations in forest soils is limited. Presently, the production of EMM by ectomycorrhizal (EM) fungi has been

D. Epron

UMR INRA-UL Forest Ecology and Ecophysiology,

Université de Lorraine, BP70239,

54506 Vandoeuvre-les-Nancy Cedex, France

B. Kieliszewska-Rokicka

Institute of Environmental Biology, Kazimierz Wielki

University, Al. Ossolinskich 12, 85-093 Bydgoszcz, Poland

R. Kjøller

Terrestrial Ecology, Biological Institute, University of Copenhagen, Universitetsparken 15, bygning 1,

DK-2100 Copenhagen, Denmark

H. Kraigher

Slovenian Forestry Institute, Vecna pot 2,

1000 Ljubljana, Slovenia

E. Matzner · J. Neumann

Soil Ecology, University of Bayreuth, Dr. Hans Frisch Str. 1, 95440 Bayreuth, Germany

C. Plassard

INRA, UMR Eco \& Sols,

34060 Montpellier Cedex 02, France 
estimated at $\sim 140$ different forest sites to be up to several hundreds of $\mathrm{kg}$ per ha per year, but the published data are biased towards Picea abies in Scandinavia. Little is known about the standing biomass and turnover of EMM in other systems, and its influence on the $\mathrm{C}$ stored or lost from soils. Here, focussing on ectomycorrhizas, we discuss the factors that regulate the production and turnover of EMM and its role in soil $\mathrm{C}$ dynamics, identifying important gaps in this knowledge. C availability seems to be the key factor determining EMM production and possibly its standing biomass in forests but direct effects of mineral nutrient availability on the EMM can be important. There is great uncertainty about the rate of turnover of EMM. There is increasing evidence that residues of EM fungi play a major role in the formation of stable $\mathrm{N}$ and $\mathrm{C}$ in SOM, which highlights the need to include mycorrhizal effects in models of global soil $\mathrm{C}$ stores.

Keywords Decomposition - Exploration type ·

Extramatrical mycelium $\cdot$ In-growth bag .

Minirhizotron · Soil organic matter · Rhizomorphs ·

Turnover rates

\section{Introduction}

In forests, the total below-ground flux of carbon (C) represents between 25 and $63 \%$ of gross primary production (Litton et al. 2007) and has a large influence on the physical, chemical and biological properties of the soil. While the flux of $\mathrm{C}$ into and out of the soil is relatively easy to estimate, little is known about the processes behind these fluxes. The production and turnover of the extramatrical mycelium (EMM) of mycorrhizal fungi is one of the least understood of these processes, which is an obstacle in modelling ecosystem C dynamics (Chapin et al. 2009; Meyer et al. 2010). In boreal and temperate forests, which is the main focus of the review, the EMM is mainly produced by ectomycorrhizal (EM) fungi associated with trees, but the amount of mycelium produced by arbuscular mycorrhizal (AM) fungi associated with herbs and some tree species can be large especially at high soil pH (Nilsson et al. 2005). The contribution of ericoid mycorrhizas to the soil mycelium remains largely unknown (Read and Perez-Moreno 2003). The EMM plays key roles in ecological processes such as plant nutrient uptake (Harley 1989), the nitrogen (N) cycling (Hodge and Fitter 2010), mineral weathering (Landeweert et al. 2001) and survival and establishment of seedlings (Smith and Read 2008) and in plant community composition (van der Heijden et al. 1998).

The EMM of mycorrhizal fungi likely has an important role in $\mathrm{C}$ cycling in ecosystems. Firstly, C flux through the EMM is probably large, secondly, it may be important for formation of soil organic matter (SOM) and thirdly, it may directly or indirectly affect decomposition of SOM. In this paper we discuss the factors that regulate the production, standing biomass and turnover of EMM, which are crucial parameters needed to assess the overall role of EMM in C cycling. The numbers of papers that present estimates of EMM production are increasing rapidly and we are for the first time putting all these data together to estimate typical mean values for different forest types. We give some attention to the importance of EMM for the formation of recalcitrant forms of $\mathrm{C}$, its indirect and direct effects on decomposition of SOM and its contribution to fluxes of $\mathrm{CO}_{2}$ in soil respiration. The interested reader may find additional information about the importance of the EMM in recent reviews of soil organic matter decomposition (Talbot et al. 2008), below ground litter quality (Langley and Hungate 2003), mineral weathering (van Schöll et al. 2008; Rosling 2009), soil aggregation (Rillig and Mummey 2006), mycelial networks (Simard 2009), C cycling (Jones et al. 2009; Cairney 2012), N cycling (Wu 2011), phosphorus (P) uptake (Cairney 2011) and broader ecological scopes (Read and Perez-Moreno 2003; Finlay 2008; Leake et al. 2004; Allen 2007; Courty et al. 2010; Hodge et al. 2010). In this review we focus on EM symbioses, these being the most important mycorrhizal type on trees in temperate and boreal forests (Read and Perez-Moreno 2003), but we make some comparisons with AM fungi. Much of the knowledge we have concerning the EMM is based on laboratory microcosm and pot studies, although an increasing number of studies are performed in situ, facilitated by techniques such as mycelium in-growth bags, chemical, molecular or isotopic markers and large scale manipulations such as trenching and girdling experiments (Nylund and Wallander 1992; Ekblad and Näsholm 1996; Ekblad et al. 1998; Wallander et al. 2001; Dickie et al. 2002; Johnson et al. 2002; Leake et al. 2006; Högberg et al. 2010; 
Heinemeyer et al. 2007, 2011 and see Wallander et al. 2013 for a discussion of advantages and disadvantages of these methods).

\section{Assessing mycelial growth: which structures to look at and where?}

Morphological heterogeneity: fine hyphae and rhizomorphs

Understanding the importance of the EMM of EM fungi in $\mathrm{C}$ cycling requires accurate predictions of mycelial growth. Detailed studies of soil microcosms in laboratory conditions show wide variation in growth rates and morphology between mycorrhizal mycelial systems of EM fungi (e.g. Duddridge et al. 1980; Finlay and Read 1986; Bending and Read 1995; Donnelly et al. 2004; Rosling et al. 2004). In many EM fungi, hyphae progressively aggregate behind the growing front to form rhizomorphs that are typically hydrophobic and long-lived (e.g. Unestam 1991; Unestam and Sun 1995; Agerer 2001). All mycelium types explore the soil via fine hydrophilic hyphae, often with substrate particles adhering to the surface, so-called 'substrate adhesion hyphae' or 'exploiting hyphae'. Few quantitative data on the relative proportion of rhizomorphs versus single hyphae of a mycelium are available. In a laboratory study of Pisolithus tinctorius in symbiosis with Pinus taeda seedlings, the rhizomorphs contributed to only $7 \%$ of the length of the mycelium but their dry matter was twice that of the diffuse mycelium (Rousseau et al. 1994). The rhizomorph proportion of the EMM probably has a large impact on its standing biomass and turnover rate (see section on EMM standing biomass and turnover below). Rhizomorphs may be a more energetically efficient means of supporting an increasingly extended mycelium over large areas (Donnelly et al. 2004).

\section{Exploration types}

Based on the amounts of emanating hyphae and the presence and differentiation of rhizomorphs, Agerer (2001) defined five main exploration types, ranging from contact exploration types with smooth mycorrhizal tips having only a few short emanating hyphae, via short and medium exploration types to long distance exploration types with highly differentiated rhizomorphs.
Exploration types have been differentiated based on about 400 different morphotypes of ectomycorrhizas (www.deemy.de; Agerer and Rambold 2004-2011), representing about $5 \%$ of known fungi that can form EM (Taylor and Alexander 2005). From this limited database, it appears that in many genera all known species produce only one exploration type, e.g. species in most of the investigated genera of the Boletales belong to the long-distance exploration type that has hydrophobic rhizomorphs, while in other genera, e.g. Russula and Lactarius, the exploration type varies between different species and can range from contact, to medium distance or even long distance exploration types (Agerer 2001; Kraigher et al. 2008; Hobbie and Agerer 2010). An EM community's species composition is made up of a range of exploration types, suggesting a degree of separation of function between them.

Where do EMM develop (organic vs mineral soil)?

The spatial heterogeneity in EMM production and standing biomass is high and laboratory soil microcosm experiments have shown that local 'hot-spots' of various inorganic and organic materials stimulate the growth of EM mycelium (e.g. Finlay and Read 1986; Unestam 1991; Bending and Read 1995; PerezMoreno and Read 2000; Jentschke et al. 2001; Rosling et al. 2004). Field demonstration of such effects comes from the observation of the stimulation of mycelial in-growth into bags spiked with inorganic $P$ sources (Hagerberg et al. 2003; Nilsson and Wallander 2003; Potila et al. 2009) or wood ash (Hagerberg and Wallander 2002) placed in conifer forest soils, and from the formation of hyphal mats in some forests (Cromack et al. 1979; Unestam 1991; Ingham et al. 1991). The higher accumulation of hyphal biomass in these patches is supported by studies of ${ }^{14} \mathrm{C}$ allocation (Finlay and Read 1986; Bending and Read 1995; Leake et al. 2001; Rosling et al. 2004).

Although EM fungi can proliferate into leaf litter in laboratory microcosms (Unestam 1991), the few studies from the field suggest that they do not grow on or utilize young litter material in the forest floor (Treseder et al. 2006; Lindahl et al. 2007). In one of the few studies carried out in forests, new litter was dominated by saprotrophs while EM fungi dominated in old litter, the underlying mor layer and in mineral soil (Lindahl et al. 2007), suggesting that saprotrophs are more competitive in the litter layer. There might be 
a niche differentiation not only between EM fungi and saprotrophs but also between exploration types, species and genotypes of mycorrhizal fungi. In support of this, the EM community structure was shown to differ between soil layers estimated both as mycorrhizal root tips (Dickie et al. 2002; Landeweert et al. 2003; Rosling et al. 2003; Tedersoo et al. 2003; Genney et al. 2006; Lindahl et al. 2007) and the EMM (Landeweert et al. 2003). Based on analyses of mycorrhizal root tips, half of the fungal taxa were restricted to the mineral soil in a podzol of a 60-80 year old Picea abies forest (Rosling et al. 2003).

\section{Estimation of mycelial growth rates and production in forest ecosystem}

Measurement of hyphal length and growth rates using microcosms (in the lab) or minirhizotrons (in the field)

Growth rates of EM hyphae in laboratory microcosm are typically 2-4 mm day ${ }^{-1}$ (Read 1992), with maximal rates of up to $8 \mathrm{~mm} \mathrm{day}^{-1}$ (Donnelly et al. 2004). Similar growth rates were recorded in an outdoor experiment using $2 \mathrm{~m}$ tall mesocosms filled with peat. In this work, a maximum growth rate of $2 \mathrm{~mm}_{\text {day }}{ }^{-1}$ for Laccaria proxima, which does not form rhizomorphs, and of $3 \mathrm{~mm}$ day $^{-1}$ for Thelephora terrestris, which forms rhizomorphs, was recorded in July (Coutts and Nicholl 1990). An indirect way to estimate the mycelial growth rate in the field may be to measure the size of genets formed by mycorrhizal fungi on trees planted on areas that have not been covered by plants previously, e.g. large sand pits. A genet size of up to $5 \mathrm{~m}$ was found for Suillus bovinus (long distance exploration type) in a sand pit with 20years-old Pinus sylvestris (Dahlberg and Stenlid 1994). This would imply a genet growth rate of $25 \mathrm{~cm} \mathrm{yr}^{-1}$ over the 20 years, equivalent to an increase of the genet radius of $0.7 \mathrm{~mm} \mathrm{day}^{-1}$ over the growing season, assuming that the mycelium growth period is similar to that of the vegetation, which is about 180 days at this site. This rate, which is somewhat lower than the rates recorded in microcosms, is without doubt lower in some periods of the season and significantly higher in others (see further on seasonal variations below).

Some rhizomorph-forming fungi produce dense mycelial mats, in which the rhizomorphs can represent
$30-50 \%$ of soil dry matter (Ingham et al. 1991). The hyphal length varies greatly from $2-600 \mathrm{~km} \mathrm{~g}^{-1}$ soil in the mats to only $0.3-0.8 \mathrm{~km} \mathrm{~g}^{-1}$ in nearby non-mat soil (Ingham et al. 1991), although some mycelial necromass might also have been included in this standing biomass measurement. The mycelial length varies not only spatially but also seasonally; the total mycelial length varied seasonally from 100 to $800 \mathrm{~m}$ $\mathrm{g}^{-1}$ soil in the organic mor layer and from 50 and 150 $\mathrm{m} \mathrm{g}^{-1}$ in the upper $10 \mathrm{~cm}$ of the mineral soil of a boreal Pinus sylvestris forest (Söderström 1979).

Minirhizotrons have been used in a few studies of rhizomorph growth (Treseder et al. 2005; Vargas and Allen 2008; Pritchard et al. 2008). However, growth in such studies is recorded as rhizomorph length per photographed frame area, making comparisons with the measurements of expansion of the mycelial front difficult. Nevertheless, yearly growth rates of $0.1-0.6$ $\mathrm{mm}$ per frame were recorded in a Pinus taeda forest, suggesting growth rates of $<1 \mathrm{~cm} \mathrm{~m}^{-2}$ of frame surface day $^{-1}$, while in a mixed conifer/oak forest, maximum rates of $100 \mathrm{~cm} \mathrm{~m}^{-2}$ of frame surface day ${ }^{-1}$ were observed (Vargas and Allen 2008), suggesting that the importance of rhizomorph forming fungi can differ very much between different forest sites.

The use of in-growth bags, a method that targets ECM (compared to saprotrophs) and enables us to estimate the production of EMM

One difficulty when making measurements of EMM production in the field is to separate the mycorrhizal mycelium from that of saprotrophs. This step has been facilitated by the use of mycelial in-growth bags (Wallander et al. 2001) or in-growth cores (Godbold et al. 2006; Hendricks et al. 2006). The bags, usually filled with sand, are made of nylon with a typical mesh size of $50 \mu \mathrm{m}$ allowing the ingrowth of hyphae but not of roots. Saprotrophs can grow into these bags but the fungal biomass within them seems to be dominated by mycorrhizal fungi as judged from trenched controls as well as DNA analyses (Wallander et al. 2001; Kjöller 2006). Using this technique EMM production rates have been estimated at $\sim 140$ different forest sites (Table 1). The majority of these sites (107) are located in Sweden, and Picea abies is the dominating tree species. Data have also been reported from Denmark (15 sites), Finland (13 sites), North America (2 sites) and France (1 site). These studies indicate an average 
production rate in the upper $10 \mathrm{~cm}$ of a forest soil of $160 \mathrm{~kg}$ dry matter ha ${ }^{-1}$ year $^{-1}$ (Table 1 ). However, this rate varies tremendously between sites, e.g. from $20 \mathrm{~kg} \mathrm{ha}^{-1}$ over 12 months in some Quercus robur sites in southern Sweden (Nilsson et al. 2007) to $980 \mathrm{~kg}$ dry matter ha ${ }^{-1}$ over 4 months in a Pinus taeda plantation at low elevation in North Carolina (Parrent and Vilgalys 2007). It can also vary greatly from year to year at the same site, e.g. in a $P$. abies plantation on a peat soil south west of Sweden, it was close to zero 1 year, but found to be $100 \mathrm{~kg}$ dry matter ha ${ }^{-1}$ the year after (R. G. Björk and A. Ekblad, unpublished). This large variation may derive from the factors regulating EMM production as well as from differences in the various methods used to assess mycelial biomass (ergosterol, phospholipid fatty acids, dry matter etc.; see Wallander et al. (2013)). Although EMM production data exist from a number of sites, there is a strong bias towards Norway spruce ( $P$. abies) and southern Scandinavia and data from other areas and other forest types are needed.

Most published data reflect the production of EMM in the upper $10 \mathrm{~cm}$ of the soil (which includes the organic layer). However, EMM production can also be high in deeper soil layers as shown in the few studies which report values from more than one soil depth (Table 1). Thus, of the $590 \mathrm{~kg} \mathrm{ha}^{-1}$ year $^{-1}$ of EMM biomass produced down to $30 \mathrm{~cm}$ depth in a Picea abies forest, half was found in the upper $10 \mathrm{~cm}$ and half in the 10-30 cm depth (Wallander et al. 2004), a distribution pattern similar to that of fine roots in this forest (Thelin et al. 2002). Other studies have also shown that the distribution of EMM generally follows that of tree fine roots (Korkama et al. 2007; Pritchard et al. 2008).

The production rates estimated by in-growth bags can be compared to the very few estimates of $\mathrm{C}$ allocation to EMM in forests. Recently, Hobbie (2006) surveyed the $\mathrm{C}$ allocation patterns of EM plants in 14 culture (laboratory) studies and five field studies. Using the data in Hobbie (2006), we estimate that on average $4.7 \%$ of total NPP ( $9 \%$ of below ground NPP) in the culture studies and $7.2 \%$ of total NPP (13\% of below ground NPP) in the field studies was allocated to the EMM. If we combine these values together with NPP estimates ranging from 333 to $590 \mathrm{~g} \mathrm{C} \mathrm{m}^{-2}$ year $^{-1}$ in three 40 -yearold Swedish P. abies forests (Berggren Kleja et al. 2008), we estimate a NPP of the EMM of $16-42 \mathrm{~g} \mathrm{C} \mathrm{m}^{-2}$ year $^{-1}$ or $350-940 \mathrm{~kg}$ dry matter ha ${ }^{-1}$ year $^{-1}$ (assuming a $\mathrm{C}$ content of $45 \%$ of dry matter). These numbers, which estimate the mycelium production in the whole soil profile, are comparable with the estimates of EMM production in $P$. abies forest soils using ingrowth bags. From the data available in Table 1 we estimate an EMM production in the upper $10 \mathrm{~cm}$ of soil in a 40-year-old Swedish $P$. abies forests to be around $200 \mathrm{~kg}$ dry matter $\mathrm{ha}^{-1}$ year $^{-1}$ and for the whole soil profile this value should probably be at least doubled.

\section{Factors regulating the carbon supply for EMM production in forest soils}

The EMM is fuelled by $\mathrm{C}$ from the host and any factors regulating $\mathrm{C}$ availability from the host-plant such as global change, weather conditions, forestry management and plant properties as well as intrinsic properties of fungal $\mathrm{C}$ use can potentially cause large variations in EMM production of EM fungi (Fig. 1) that will further sustain differences between sites, seasons and years.

Seasonal effects and forest aging

Seasonal variations in EMM production may be driven by abiotic variables notably light, temperature and moisture but also by phenological phenomenon, both in the hosts and symbionts (for moisture effects see further down).

The growth of EM fungi is mainly dependent on newly produced photosynthates (Söderström and Read 1987; Högberg et al. 2001; Johnson et al. 2002; Högberg et al. 2010; Steinman et al. 2004). The major growth of EMM is therefore expected to occur when below-ground allocation of carbohydrates is relatively large, shortly after fine root production has peaked. In a cool temperate climate this is late summer to early autumn (July-October), while in a temperate planted spruce-beech forest in Bavaria the peak in beech fine root production was in June (Grebenc and Kraigher 2007). Indeed, in a northern boreal Pinus sylvestris forest, below-ground $\mathrm{C}$ allocation in late August can be 5 times that in mid June (Högberg et al. 2010). While in a temperate forest in France, the belowground ${ }^{13} \mathrm{C}$ allocation after pulse labelling of beech trees was much higher in July than in May and late August (Epron et al. 2011). The few published studies on temporal variations in the production of EMM of EM fungi fit with this view (Lussenhop and Fogel 1999; Wallander et al. 2001; Nilsson et al. 2007). In 
ヨสิ่

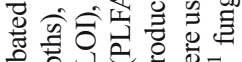

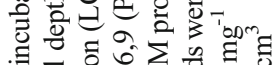

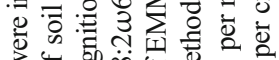

उप

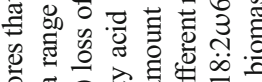

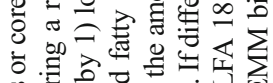

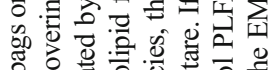

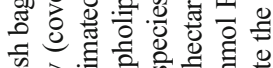

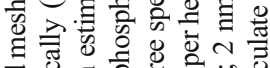

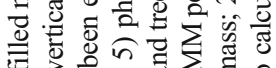

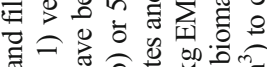

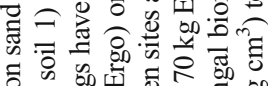

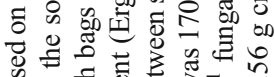

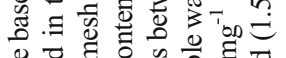

芯

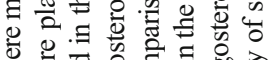

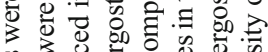

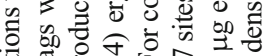

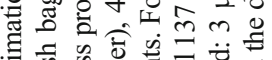

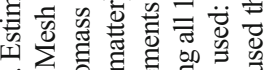

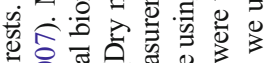

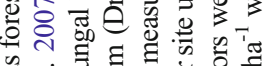

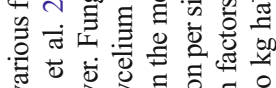

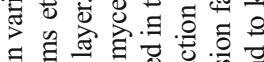

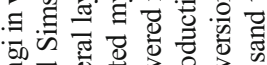

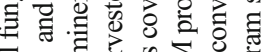

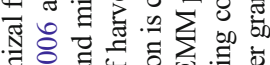

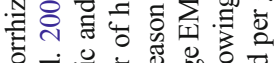

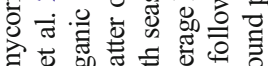

㻤总

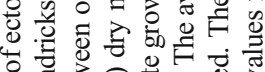

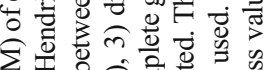

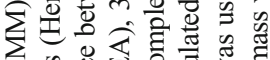

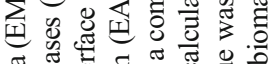

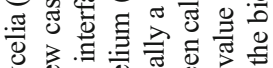

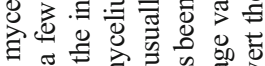

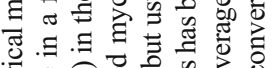

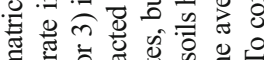

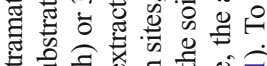

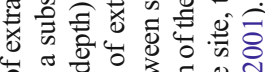

ส

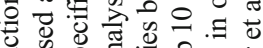

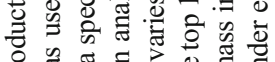

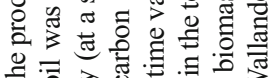

Е

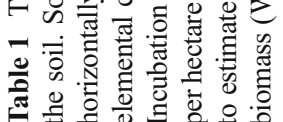

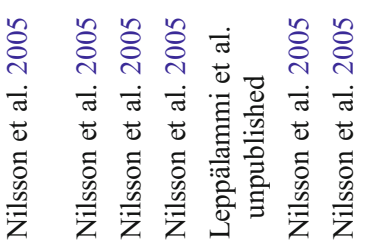

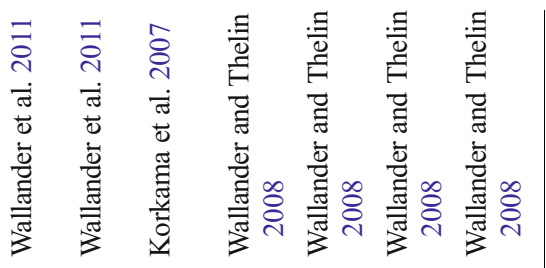

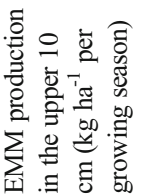

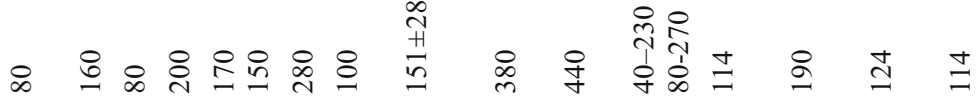

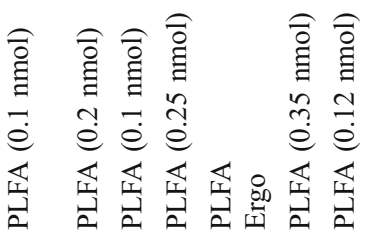

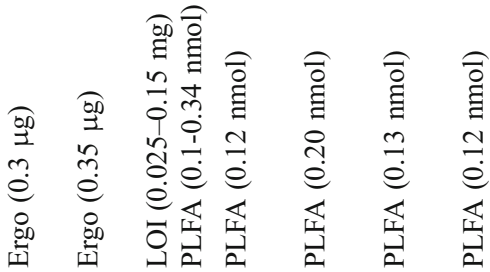

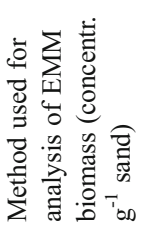

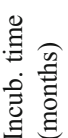

$+\quad+\quad \mathrm{I} \quad+$

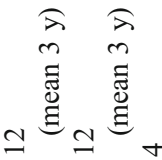

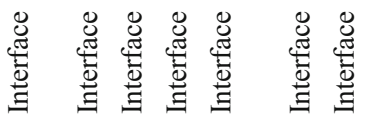

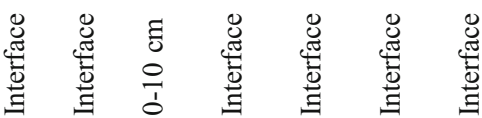

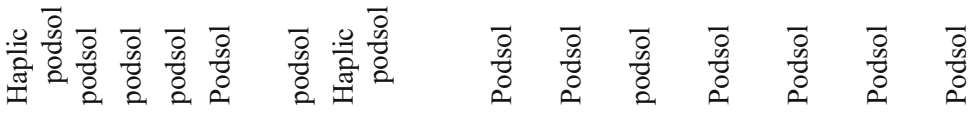

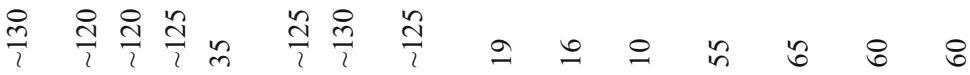

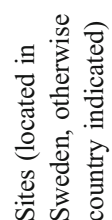

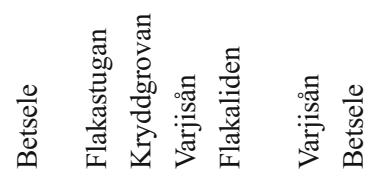

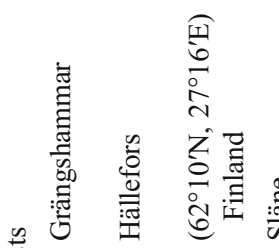

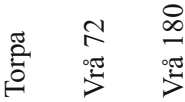




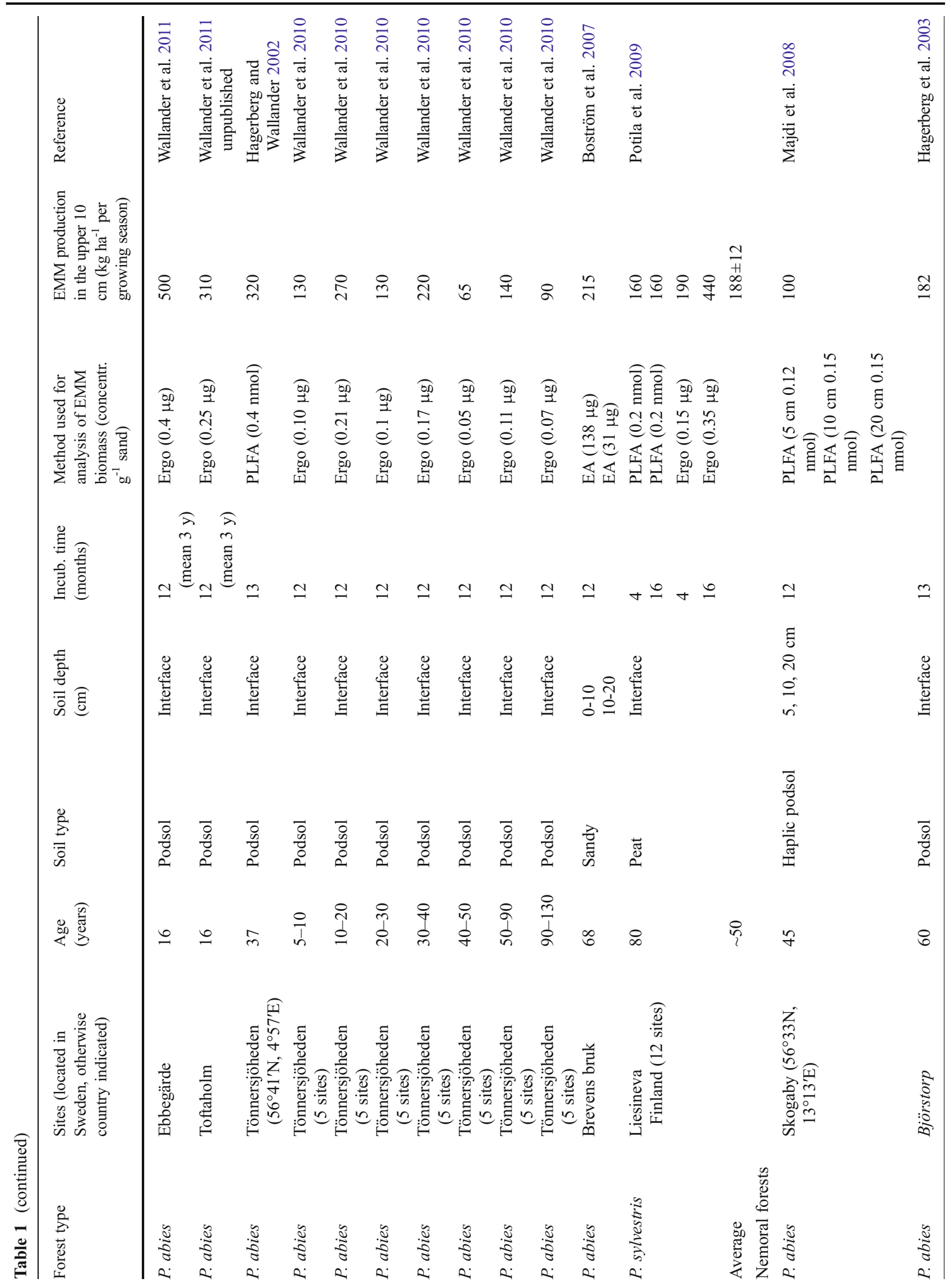




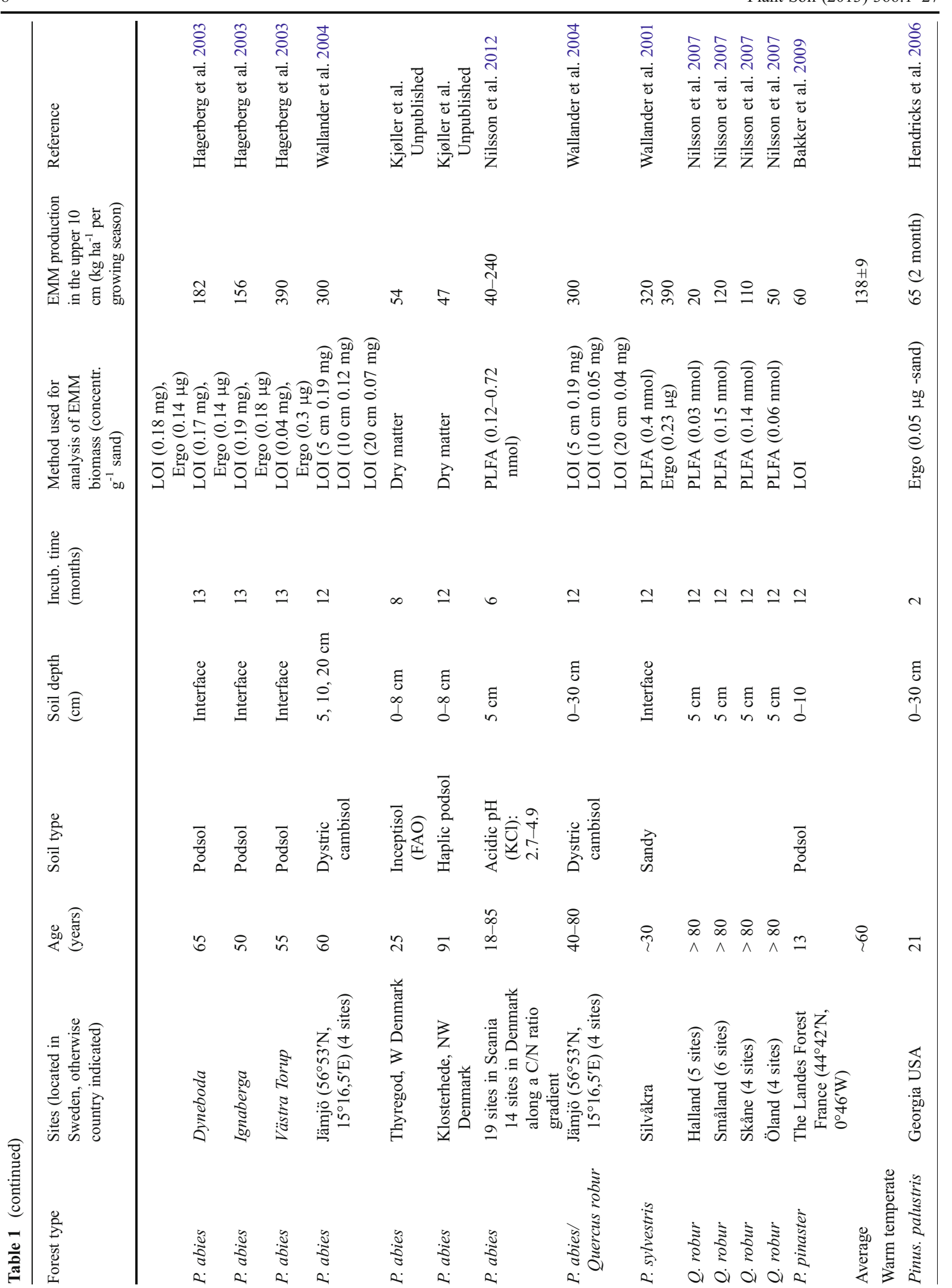




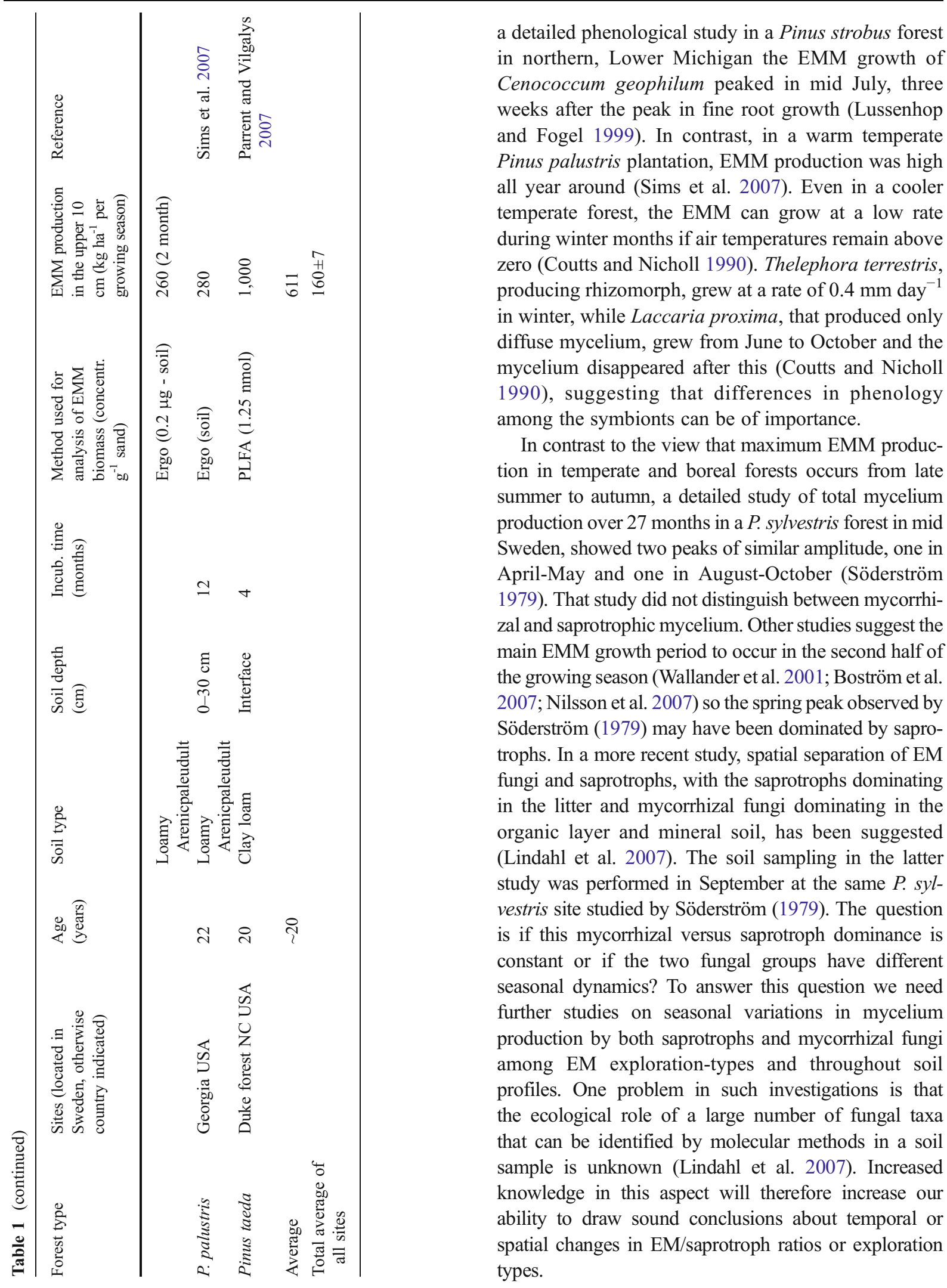


In addition to the yearly effect of season, a multitude of changes take place in an ecosystem over a forest cycle. The most dramatic changes in plant cover, species composition, soil chemistry, hydrology, climate etc. occur directly after tree harvest and then up to canopy closure after which the changes are slower. There are therefore many factors that may directly or indirectly affect EMM production and its standing biomass. Many of these are probably connected to successional changes in species composition above and below ground as well as changes in below ground $\mathrm{C}$ allocation, but EMM production has not been studied greatly in this context (Last et al. 1987). Tree growth varies over a rotation period, usually with a peak around canopy closure when nutrient demand also reaches a maximum (Kimmins 2004). This occurs between 25 to 40 years of age in $P$. abies forests in central-southern Sweden (Schmalholz and Hylander 2009). The production of EMM seems to peak around the time when tree growth is highest (Wallander et al. 2010; Kalliokoski et al. 2010).

Effect of elevated atmospheric $\mathrm{CO}_{2}$

In agreement with the fact that EM fungi rely on $\mathrm{C}$ supplied by the host, several studies have shown a stimulation of EMM production under elevated atmospheric $\mathrm{CO}_{2}$ concentrations (e.g. Godbold et al. 1997; Treseder 2004; Alberton et al. 2005; Fransson et al. 2005; Alberton and Kuyper 2009). However there are exceptions, for example Weigt et al. (2011) found no increase or only a slight increase in EMM length using seedlings of Picea abies inoculated with Piloderma croceum and exposed to double or ambient $\mathrm{CO}_{2}$ concentration alone or in combination with addition of ammonium nitrate solution. The effect of elevated $\mathrm{CO}_{2}$ on EMM production has mostly been studied in laboratory grown seedlings. The few results available from field studies fail to show a $\mathrm{CO}_{2}$ effect on EMM production (Kasurinen et al. 2005; Godbold et al. 2006; Parrent and Vilgalys 2007). A response shown in many laboratory and some field experiments is that changes in $\mathrm{C}$ availability causes an increase in the degree of mycorrhization (Godbold et al. 1997; Garcia et al. 2008). But in forests types, such as Boreal forest where the tree root tips are close to $100 \%$ colonized by EM fungi (Taylor and Alexander 2005), a response to $\mathrm{CO}_{2}$ is unlikely to be of great significance. More generally the EM-fungal community has been shown to change both in experiments with elevated $\mathrm{CO}_{2}$ (e.g.; Godbold et al. 1997; Fransson et al. 2001;
Parrent et al. 2006; Parrent and Vilgalys 2007) and in defoliation experiments (Saikkonen et al. 1999; Cullings et al. 2001; Markkola et al. 2004; Saravesi et al. 2008). The change in EM-fungal community has often manifested itself in a shift between morphotypes differing in mantle thickness. A reduction in C availability, by e.g. defoliation, seems to favour smooth mycorrhizal types and disfavour types that produce thick mantles and rhizomorphs (Saikkonen et al. 1999; Cullings et al. 2001; Markkola et al. 2004; Saravesi et al. 2008). So far one laboratory study has reported an increased proportion of mycorrhizas producing thick mantles and abundant rhizomorphs in response to elevated $\mathrm{CO}_{2}$ (Godbold et al. 1997), and only one of the few field studies showed that rhizomorph production was almost doubled by elevated $\mathrm{CO}_{2}$ in deeper soil layers in a Pinus taeda forest (Pritchard et al. 2008). The production of EMM varies greatly between different exploration types (Weigt et al. 2011) and it seems reasonable to find increased abundance of high $\mathrm{C}$ demanding exploration types when $\mathrm{C}$ availability is increased by elevated $\mathrm{CO}_{2}$. Clearly further field studies on the effects of elevated $\mathrm{CO}_{2}$ on mycelium production are needed.

Effect of soil fertility and potential use of a stoichiometric $\mathrm{C}: \mathrm{N}: \mathrm{P}$ model for understanding fungal $\mathrm{C}$ allocation in response to $\mathrm{N}$ and $\mathrm{P}$ fertilization

Among the factors that can affect the $\mathrm{C}$ availability for mycelium production, site fertility - and thus fertilization practices, may strongly regulate belowground $\mathrm{C}$ allocation (Fig. 1). Trees allocate proportionally more $\mathrm{C}$ to shoots and less to roots at sites with high productivity while at sites of low productivity proportionally more $\mathrm{C}$ is allocated belowground to enhance nutrient uptake by roots and EM fungi (Högberg et al. 2003). However, since high fertility also results in high photosynthesis, the total amount of $\mathrm{C}$ allocated below ground may sometimes be larger at a more productive site than at a less productive site. Indeed, a positive correlation between EMM biomass and site fertility was found in mixed boreal forests in Finland (Kalliokoski et al. 2010) and fast-growing $P$. abies clones produced more EMM than slow growing clones (Korkama et al. 2007). It was shown that the fast growing clones hosted EM fungi that belong to the types that produce extensive mycelia with rhizomorphs, e.g. Piloderma, while the slower growing clones had more fungi that produce less mycelium such as the Ascomycete Wilcoxina (Korkama et al. 2007). 


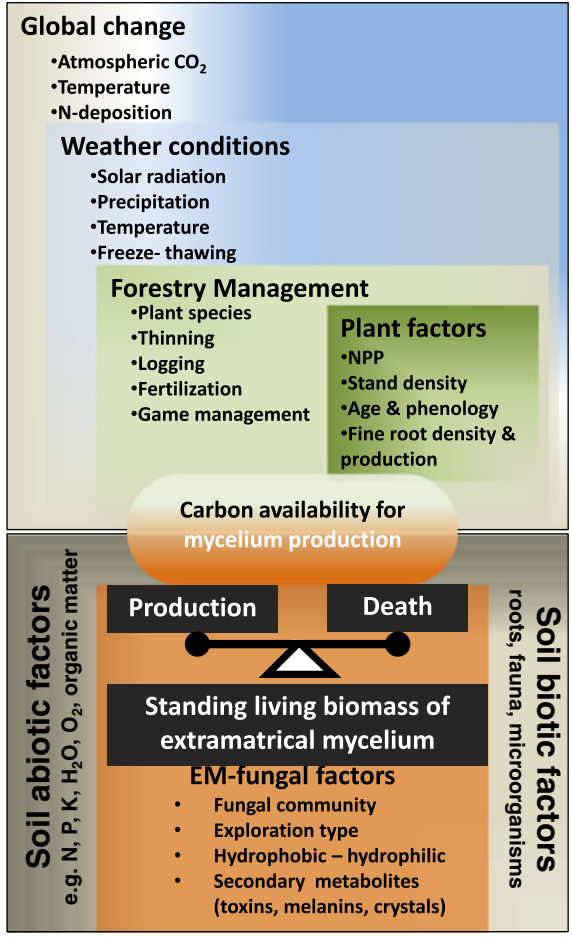

Fig. 1 Overview of the factors that directly or indirectly may affect the production, standing biomass and death of the extramatrical mycelium of ectomycorrhizal fungi

However, when site fertility was increased by high $\mathrm{N}$ fertilization of forests, it resulted in reduced production of EMM by the EM fungi (Kårén and Nylund 1997; Nilsson and Wallander 2003; Sims et al. 2007; Högberg et al. 2011), while the effect on mycorrhizal colonization on roots is usually much smaller (Kårén and Nylund 1997; Treseder 2004). This reduction in EMM production may be caused both by a lower standing fine root biomass at high $\mathrm{N}$ (Nadelhoffer 2000) as well as that large amount of $\mathrm{C}$ is needed to take up and assimilate the excessive $\mathrm{N}$ in the fertilized plots (Bidartondo et al. 2001; Ek 1997). This $C$ consumption may result in $C$ limitation of EMM production (Wallander 1995). Under unbalanced nutrient conditions, much of the excess $\mathrm{N}$ is transported to the shoot and is stored in the vacuoles in the leaf in the form of amino acids (Näsholm et al. 1997). In laboratory microcosms, a cessation of EMM growth was noted when the mycelial front of certain species reached peat amended with inorganic $\mathrm{N}$ (Arnebrant 1994). Different species seems to be more or less sensitive to high inorganic $\mathrm{N}$ concentrations and high $\mathrm{N}$ fertilization typically causes changes in the species composition of EM fungi making the smooth mycorrhizal types more common (e.g. Kårén and Nylund
1997; Parrent and Vilgalys 2007). Accordingly, Gorissen and Kuyper (2000) applied the terms nitrophilic and nitrophobic species based on their tolerance of inorganic N. Laccaria bicolor, a nitrophilic species, retained more $\mathrm{N}$ in the fungal biomass while the $\mathrm{N}$ sensitive (nitrophobic) Suillus bovinus delivered more $\mathrm{N}$ to the host plant when studied in a pot experiment (Gorissen and Kuyper 2000). This would imply that nitrophobic species spend more $\mathrm{C}$ on $\mathrm{N}$ assimilation and amino acid transfer to their host plant while nitrophilic species can tolerate $\mathrm{N}$ by spending less $\mathrm{C}$ on $\mathrm{N}$ assimilation, which would allow them to spend more $\mathrm{C}$ on EMM growth under excess N. Difference in $\mathrm{C}$ demand and tolerance to specific elements by individual EM species in forest soils may be one explanation for the high diversity usually found in such communities.

In contrast to the negative effect of high doses of $\mathrm{N}$ on EMM production, intensive fertilization with a balanced nutrient mix, including all elements needed, resulted in no change in EMM production in two sites but a reduction in a third site (Wallander et al. 2011). This suggests that the balance between the availability of $\mathrm{C}$ and $\mathrm{N}$ and possibly other nutrients is of importance. Recently, Johnson (2010) recommended a stoichiometric C:N:P perspective to provide the basis for a more predictive understanding of fertilization responses of AM symbioses to $\mathrm{N}$ and $\mathrm{P}$ fertilization. It was predicted that the function of the AM symbiosis is dependent on the availability of $\mathrm{N}$ and $\mathrm{P}$ such that the mutualistic benefit is greatest at the combined condition of high $\mathrm{N}$ and low $\mathrm{P}$, which would give high photosynthesis rates when the symbiont is efficient in P uptake. Furthermore, the study also predicted the response of plant and fungal morphology to a change in resource availability, e.g. $\mathrm{N}$ fertilization can induce $\mathrm{P}$-limitation, which would result in more $\mathrm{C}$ allocation to production of roots and AM fungi. Johnson (2010) brings up several field and laboratory experiments supporting these models for AM symbioses. In EM symbioses, localized additions of inorganic $\mathrm{N}$ can stimulate the proliferation of mycelium production, at least of some fungi (Jentschke et al. 2001; Clemmensen et al. 2006). However, as pointed out above, large scale $\mathrm{N}$ fertilization in temperate and boreal forests is known to result in reduced production of EMM (Kårén and Nylund 1997; Nilsson and Wallander 2003). The reason for this discrepancy between AM and EM systems is unknown but it may be that $\mathrm{P}$ availability is not low enough in many temperate and boreal forests to allow $\mathrm{N}-$ induced $\mathrm{P}$ limitation to develop over the experimental 
period. It has been shown that $\mathrm{N}$ fertilization can give rise to $\mathrm{P}$ limitation of forest production in boreal P. abies forests in long-term factorial fertilizer experiments (Tamm 1991), but it remains to be shown what happens to the EMM production in such experiments. Indeed, laboratory experiments on Pinus sylvestris seedlings with EM showed very high EMM production at the combination of high N, low P conditions (Wallander and Nylund 1992; Ekblad et al. 1995). It should be noted that in the paper by Wallander and Nylund (1992), there were similar EMM production responses to the $\mathrm{N}$ and $\mathrm{P}$ conditions in both the nitrophilic Laccaria bicolor as well as in the nitrophobic Suillus bovinus. This suggest that a C:N:P perspective may be valid for a nitrophobic as well as a nitrophilic species when studied separately. However, in the soil with many different species competing for a living space on the same tree root system, species differences in the $\mathrm{C}$ and $\mathrm{N}$ use (see above) could potentially have large impact on the competition between species. Phosphorus fertilization of naturally $\mathrm{P}$-limited soils would be an alternative way of testing the validity of the C:N:P model for EM symbioses. Peat soils are naturally low in $\mathrm{P}$ and $\mathrm{K}$ and recent results from a long lasting PK-fertilizer experiment on a drained peatland show that the production of EMM, as well as the colonization of roots, was stimulated by low P availability, and the EMM production was also stimulated by low $\mathrm{K}$ conditions (Potila et al. 2009). These results also support the applicability of a stoichiometric C:N:P model for EM symbioses. The availability of different forms of $\mathrm{N}$ and $\mathrm{P}$, and the ability of different species and genotypes of EM fungi to use them may also be important factors in regulating tree growth and $\mathrm{C}$ allocation feedbacks. We identify the need for studies of EMM production in long-term factorial $\mathrm{N}, \mathrm{P}$ fertilizer experiments in forest ecosystems to further test the C:N:P model for EM symbioses.

\section{Abiotic and biotic factors regulating mycelial growth}

Soil moisture

Extramatrical mycelium production can be sensitive to soil moisture, for example it can be reduced by $50 \%$ in a dry year compared to a wet year in a well-drained $P$. abies forest (Majdi et al. 2008). However, it appears that mycelial production, at least of some fungal species, is not as sensitive to drought as sporocarp production, which responds strongly to soil moisture conditions
(Wiklund et al. 1995). Indeed, despite a very dry year with very few fruiting bodies produced, high mycelial in-growth in the upper $6 \mathrm{~cm}$ of the soil was found in a $P$. taeda forest (A. Ekblad et al. unpublished). Production of EMM can be extensive in the deeper mineral soil (Wallander et al. 2004; Boström et al. 2007; Majdi et al. 2008) and so potentially a reduced production of mycelium in the surface could be compensated for by an increase in production or a slower turnover rate further down in the soil (Pritchard et al. 2008). The survival and growth of mycelia during drought conditions may be enabled by the passive movement of water from deeper moist soils to dryer surface soils via roots by so called nocturnal hydraulic lift (Caldwell et al. 1998; Querejeta et al. 2003, 2007). Indeed, ${ }^{18} \mathrm{O}$ tracer experiments indicate that sporocarps of fungal species formed during very dry conditions derived $30-80 \%$ of their water from hydraulically-lifted or deep water (Lilleskov et al. 2009). Recently, an experiment using deuterium labelled water presented strong evidence for hydraulic redistribution of soil water by a common mycorrhizal network from mature trees to seedlings under field conditions (Warren et al. 2008).

Periodically dry habitats seem to be dominated by rhizomorph-forming fungi, many of them hydrophobic (Unestam 1991). Wet conditions may instead be detrimental to rhizomorph-formers since laboratory studies show that mycorrhizal colonization of hydrophobic but not hydrophilic fungi may be hampered by wet conditions (Stenström 1991). In fact, recent minirhizotron data show that rhizomorph length was negatively correlated with soil water content in a mixed conifer and oak forest and daily recordings show that the rhizomorphs grew rapidly at very low soil water content, so it was hypothesised that plants invest in C for rhizomorphs in exchange for water during harsh conditions (Vargas and Allen 2008).

\section{Grazing effects}

Grazing of above ground plant parts normally consumes a minor part of net primary production in forests and usually has minor effects on the standing plant biomass in such ecosystems (Kimmins 2004). However, grazing is selective and can have significant impact on plant species composition in a community (Pastor and Naiman 1992; Persson et al. 2000) and may therefore indirectly affect species composition of mycorrhizal fungi (Gehring and Whitham 2002), and consequently also 
have effects on EMM production. Severe grazing of leaves can result in drastically reduced photosynthesis, reduced $\mathrm{C}$ allocation below ground and reduced mycelium production, similar to that of experimental defoliation (see above).

The presence of fungivores as well as of other soil organisms could potentially affect growth, standing biomass and turnover of the EMM in the soil. Laboratory microcosm experiments suggest that the growth of EMM may be reduced, unaffected or stimulated by the presence of grazing invertebrates such as collembola. The direction of this change may be determined by the species composition and population density of the fungivores (Fitter and Sanders 1992; Ek et al. 1994; Setälä 1995; Setälä et al. 1999). However, it is not clear to what extent changes in EMM biomass are a direct effect of animal grazing or the result of other processes acting indirectly on the EMM (Setälä et al. 1999) involving e.g. selective grazing of competing saprotroph fungi, recycling of minerals locked up in senescing tissues or removal of growth inhibitors (Fitter and Sanders 1992). Indeed, soil arthropods significantly affect the rate of $\mathrm{N}$ mineralization in forest soils (Persson 1989).

As with grazing above ground, below ground grazing is probably selective. This selection may be directed by the fungal odour (Bengtsson et al. 1988; Bengtsson et al. 1991) together with contents of defence substances (e.g. crystals on the surface and content of repellents) rather than its $\mathrm{C}$ and $\mathrm{N}$ content (Taylor and Alexander 2005; Böllmann et al. 2010). The vitality of the mycelium may also be important because severed mycelium, and mycelium of Pisolithus tinctorius grown on agar was grazed more by the collembolan Folsomia candida than mycelium connected to a host plant (Kaneda and Kaneko 2004). Many fungi produce bioactive secondary metabolites that have been shown to be nematicidal (Stadler and Sterner 1998), e.g. many Lactarius and Russula species produce the biologically inactive precursor stearoylvelutinal that after a wound is rapidly converted to strongly antibiotic and pungent sesquiterpenoids (Stadler and Sterner 1998; Spiteller 2008). The EM fungus Laccaria bicolor was even shown to paralyse, probably by a toxin, and then invade and kill the springtail F. candida (Klironomos and Hart 2001). The $\mathrm{N}$ in the springtail was found to be beneficial for growth of the host plant, which is a demonstration of a dramatic shortcut of the $\mathrm{N}$-cycle. It is unknown if other EM fungi have this striking capacity.
In accordance with optimal foraging theory, animals will feed on the food source yielding the greatest reproductive success (MacArthur and Pianka 1966). Laboratory experiments have shown that soil fauna can graze on EM fungi grown in vitro (e.g. Shaw 1988). In grassland, in situ ${ }^{13} \mathrm{C}$ labelling has unequivocally demonstrated that collembola can significantly affect release of recent assimilate by external arbuscular mycorrhizal mycelium (Johnson et al. 2005). In a field ${ }^{13} \mathrm{C}$ pulse-chase experiment in a young Pinus sylvestris forest some Collembola were ${ }^{13} \mathrm{C}$-labelled within days, which was interpreted as evidence for grazing of active hyphal tips of EMM by these animals (Högberg et al. 2010). However, in this experiment, it cannot be excluded that the ${ }^{13} \mathrm{C}$ label was derived from grazing of algae or lichens on the soil surface, or from grazing of microbes in the rhizosphere, since it is known that many Collembola can feed on several different substrates (Hopkins 1997). In fact, some other recent studies suggest that the EMM of EM fungi is the optimal food for relatively few soil animals in situ. Indeed, tree girdling experiments in Sweden of two Picea abies forests and one P. sylvestris forest reduced the population of Protura and only one species of orbatid mite, Oppiella nova, but the latter was only reduced in the $P$. abies forests not in the P. sylvestris forest (Remén et al. 2008; Malmström and Persson 2011). The collembolans were either not affected or stimulated by the girdling (Malmström and Persson 2011). Furthermore, in a windfall area of a $P$. abies forest, very high densities of Protura were found in the vicinity of small $P$. abies plants, while in areas without surviving $P$. abies, the proturan density was low, supporting the view that EM fungi is an important food source for this animal group (Krauss and Funke 1999). In a microcosm experiment, it was found that $O$. nova could grow and increase its population on some EM fungi in symbiosis but not on others, while none of the other common soil animals tested succeeded to reproduce when feeding on EM fungi (Remén et al. 2010). Furthermore, in laboratory microcosm the presence of four different EM fungi grown in symbiosis with $P$. sylvestris had no effect on soil animal populations (Setälä et al. 1999; Setälä 2000). It seems that the importance of EMM as an easily available food source for the detritus soil food web could be smaller than previously believed (Setälä 2000), although more targeted experimental work needs to be undertaken under field conditions. It is 
possible that EMM should be considered a large $\mathrm{C}$ store in the soil rather than a $\mathrm{C}$ source (see further below and Setälä et al. 1999), and that grazing of saprotrophic microorganisms is relatively more important than grazing of EM fungi. If so, this may have major implications for plant-microbe interactions and the cycling of limiting mineral nutrients, such as $\mathrm{N}$ and P. For example, the positive effect of bacterial and fungal feeding nematodes on the biomass production of non-mycorrhizal $P$. sylvestris was of equivalent magnitude to the positive effects of formation of mycorrhizas, suggesting that the grazing by the nematodes released $\mathrm{N}$ that otherwise was locked into saprotroph biomass (Setälä et al. 1999).

\section{Estimation of standing biomass and turnover of EMM}

The data discussed above suggest that there is substantial amount of $\mathrm{C}$ invested in the production of EMM. However, in order to fully assess its importance in the forest $\mathrm{C}$ cycle, data on its standing biomass and turnover are required. In this section we will present the few data available, and briefly discuss the factors that may affect EMM turnover. A large standing biomass can be the result of a high production or a slow turnover or a combination of both.

The standing biomass and turnover of EMM

Laboratory studies show that mycelial fans of EM fungi, consisting of thousands of single hyphae, can develop and disappear in a few weeks (e.g. Finlay and Read 1986; Bending and Read 1995). These studies have led to the general view that EMM turnover is very rapid perhaps occurring once per week during the growing season (Finlay and Söderström 1992; Smith and Read 2008). However, it is unknown if these results of laboratory studies, typically using monocultures of EM fungi living in symbiosis with small seedlings under low light conditions, are directly applicable in the field. For field studies, quite a large number of EMM production estimates have been published (Table 1), but to calculate the turnover rate we need both production and standing biomass estimates. This is problematic due to the difficulty to distinguish mycorrhizal from saprotrophic mycelium. We know of only one study in which estimates of both standing biomass and production of EMM have been made. Using a soil-incubation technique, it was estimated that EM fungi contributed to approximately half of the standing mycelial biomass in coniferous forests soils in southern Sweden (Bååth et al. 2004). Based on these results, Wallander et al. (2004) calculated total EMM standing biomasses in the upper $70 \mathrm{~cm}$ of the soil of $4.8 \times 10^{3} \mathrm{~kg} \mathrm{ha}^{-1}$ in a P. abies forest and $5.8 \times$ $10^{3} \mathrm{~kg} \mathrm{ha}^{-1}$ in a mixed P. abies/Quercus robur forest. This is an order of magnitude higher than the production rates determined from in-growth bags, suggesting a mean residence time of 10 years (Wallander et al. 2004), or a turnover rate of about 0.1 year $^{-1}$, which is considerably lower than those of fine roots in boreal and temperate forests which have been estimated to be between 0.4-1.3 year ${ }^{-1}$ (Gill and Jackson 2000; Finér et al. 2011; Brunner et al. 2012). A mean residence time of the whole mycelium of 10 years is surprisingly high as shown above, and suggests a large contribution of longlived rhizomorphs (see below) to the standing biomass in these forests. Alternatively, this dichotomy is simply an illustration of the difficulty of estimating EMM standing biomass and production accurately. For example, one problem may be a possible underestimation of EMM production rates with the sand bags (Hendricks et al. 2006) as well as the imprecise conversion factors between fungal biomarkers and biomass. An underestimate of production combined with an overestimate of standing biomass would result in an underestimate of the rate of turnover. A solution to this problem may be to combine sequential harvesting of in-growth bags with a ${ }^{13} \mathrm{CO}_{2}$ pulse labelling of the mycelium via the plant and analyses of ${ }^{13} \mathrm{C}$ in structural components of the mycelium such as glucosamine (for further technical discussions, see Wallander et al. 2013).

\section{Rhizomorph longevity}

Different parts of the mycelium definitely turn over at different rates and it is likely that single hyphae of many fungi turn over much more rapidly than rhizomorphs. Recent minirhizotron studies show that mean life-span of rhizomorphs can range from 7 to 22 months and some can survive several growing seasons (Treseder et al. 2005; Pritchard et al. 2008; Vargas and Allen 2008). In a Pinus taeda forest exposed to elevated $\mathrm{CO}_{2}$, the average life-span of rhizomorphs was dependent on rhizomorph diameter, soil depth and the $\mathrm{CO}_{2}$ treatment (Pritchard et al. 2008). The longest average life-span was found for thick, rhizomorphs, 
at greater soil depth and under high $\mathrm{CO}_{2}$-conditions. These findings suggest that the turnover of the complete EMM is probably highly dependent on the relative contribution of rhizomorphs to the standing biomass and possibly their average diameter and soil depth distribution. Knowing that a forest's EM community is typically dominated by a few fungal species, with a large number of other species that are rare (Dahlberg 2001), even a minor shift in species composition may therefore have a profound effect on the standing biomass and turnover of the EMM. It should be noted that most rhizomorphs are hydrophobic, but some fungi, e.g. Thelephora terrestris, produce hydrophilic rhizomorphs (Unestam 1991). It is unknown if hydrophobicity affects the turnover rates, but a hydrophobic surface is probably less easily attacked by extracellular enzymes which could result in suppressed microbial degradation rates.

Rhizomorphs can be much more long-lived than roots, as demonstrated in the P. taeda forest mentioned above. In this forest, the mean life-span of rhizomorphs was 2 to 9 times longer those of the mycorrhizal tips (Pritchard et al. 2008). This difference has several important ecological implications. For instance, new roots can, at relatively low $\mathrm{C}$ and $\mathrm{N}$ costs, connect to and take advantage of all the benefits of an established extensive mycelial network. A long life-span is advantageous to the fungus which is more likely to cover a large area of the forest floor. In addition, a large mycelial network will immobilize $\mathrm{N}$, reducing the $\mathrm{N}$ leakage from the forest. Indeed, leakage of $\mathrm{N}$ after heavy $\mathrm{N}$-fertilization is suggested to be intensified due to the reduction of EMM (Högberg et al. 2011). However, the mean lifespan of rhizomorphs is not always longer than that of the root tips, as was shown in a mixed conifer oak forest (Vargas and Allen 2008). Differences in estimates of longevity may reflect the species composition of fungal communities and illustrates the need for further studies comparing the longevity of rhizomorphs and root tips.

Variation in EMM biomass and turnover

Large seasonal and year-to-year variations in standing biomass and turnover are likely due to environmental factors that directly affect the mycelium, such as winter soil freezing, but also indirect effects via the host, such as seasonal changes in $\mathrm{C}$ availability or more catastrophic events such as drastic declines in leaf area, and thus reductions in the $\mathrm{C}$ supply to the mycorrhizas. Thus, a summer drought combined with an ice storm in December of the same year resulted in reduced leaf area index and in high rhizomorph mortality, reduced production and standing biomass of mycorrhizas and rhizomorphs the following year (Pritchard et al. 2008). Since the EMM biomass contains a large pool of N, reductions in its standing biomass are likely to cause an increase in easily available $\mathrm{N}$, as indicated by the increased $\mathrm{N}$ concentration and increased $\delta^{15} \mathrm{~N}$ of dwarf shrubs the year after tree girdling in a boreal forest (Bhupinderpal-Singh et al. 2003).

Changes with soil depth in disturbances such as drying-wetting cycles are likely to result in faster turnover of mycelium in the upper soil horizons, which may at least partly explain the depth differences seen for rhizomorphs. It is not known whether there are also substrate-characteristic differences in turnover rates. Laboratory studies show that the intensive colonization of organic patches with EM mycelium is of short duration and recedes after a few weeks (e.g. Finlay and Read 1986; Bending and Read 1995; Donnelly et al. 2004). In contrast, when mineral material from the E-horizon ( $60 \%$ sand and $40 \%$ silt) of a podzol was used, the EMM grew vigorously throughout the experiments (14 to 19 weeks; Rosling et al. 2004). However, since different fungi were used in these experiments, we cannot exclude species differences as a possible source of variation rather than substrate effects. On the other hand, a substrate dependent difference in longevity was indicated when the EMM of Rhizopogon colonized either small patches with organic materials or acid washed silica sand; the mycelium disintegrated within a few weeks after colonizing the organic patch while it remained vital in the mineral patch throughout the experiment (Wallander and Pallon 2005). We propose that a substrate dependent difference in turnover would be a logical consequence of the different functions that the mycelium may fulfil. Thus, in the mineral soil the main activity of EMM is to take up minerals like $\mathrm{P}$ and $\mathrm{K}$, and additionally aid their release by the weathering of primary and secondary minerals. Weathering is a very slow process and therefore the mycelium is more persistent in these environments. In contrast, in the organic horizons, the availability of nutrients varies both temporally and spatially and the strategy is to rapidly colonize short-lived patches of labile organic matter. When the first patch is depleted, the mycelium autolyses and some of the material in the old 
mycelium is translocated to other hotspots. However, further studies are needed to test if there are substrate differences in the growth habits of EM fungi. It is also unknown how much of the fine mycelium that is autolysed and reused and how much that is decomposed by other organisms.

The direct effect of grazing by soil microarthropods on EMM production may be small (see above) but indirect effects of fauna on EMM turnover and standing biomass of mycelial materials could still be of importance, e.g. grazing or disturbance caused by activities of mesofauna and larger animals may be of importance but this is unknown. Such faunal effects on EMM turnover may vary between ecosystems, along with differences in faunal and fungal communities. For example, in soils with high activity of earthworms, such as in many broad leaved forests in Europe, the physical disturbance to the mycelium is likely to be large, which would increase the turnover of EMM and reduce its standing biomass. In areas with high density of wild boar the disturbance caused by their rooting can be tremendous (Massei and Genov 2004). Hypogeous sporocarps can contribute significantly to the wild boar diet which can stimulate the production and spread of these sporocarps (Lawrynowicz et al. 2006).

\section{Importance of mycelial C cycle for SOM formation and cycling}

The amount of C invested into EMM is large and this important component of the soil biomass may potentially affect the amount of $\mathrm{C}$ stored in SOM in several ways. Firstly, residues of the EMM may contribute to the formation of stable SOM (Godbold et al. 2006). Secondly, the activity of the mycorrhizal roots and EMM may indirectly or directly affect the decomposition of organic materials.

\section{Soil organic matter formation}

There is increasing evidence that microbial residues play an important role as precursors for stable SOM (Ehleringer et al. 2000; Godbold et al. 2006; Wallander et al. 2011), however which residues are involved remains unclear (Koide and Malcolm 2009). The precursors may both come directly from mycorrhizal tissues (Godbold et al. 2006) or as a result of microbial turnover during the degradation of plant necromass (Ehleringer et al. 2000). Much of the early evidence for the importance of microbial residues in formation of SOM is based on measurements of changes in isotopic ratios. In forest soils, there is an enrichment of ${ }^{13} \mathrm{C}$ and ${ }^{15} \mathrm{~N}$ and a decrease in $\mathrm{C} / \mathrm{N}$ ratio of the SOM with soil depth, which approaches that in the fungal biomass (Gebauer and Schulze 1991; Högberg et al. 1996; Wallander et al. 2003; Gleixner 2005; Boström et al. 2007). The enrichment of ${ }^{13} \mathrm{C}$ and ${ }^{15} \mathrm{~N}$ has been used to suggest increased importance of microbial input to SOM with increasing soil depth. In fact, the $\delta^{15} \mathrm{~N}$ signature of SOM in the mineral soil approaches that of EM fungi (Boström et al. 2007), suggesting that EMM is the main precursor of this material. In support of the idea that the EMM may be important in formation of SOM, analyses of the $\delta^{13} \mathrm{C}$ of mycelial and root in-growth cores suggested that EMM was the dominant pathway through which C entered the SOM pool (Godbold et al. 2006), contributing up to $60 \%$ of newly formed SOM. In this work, by using in-growth cores with different mesh sizes the input from the EMM could be distinguished. A greater recalcitrance of fungal substances such as chitin compared to plant residues from cellulose and lignin has been used as an explanation for the apparent accumulation of microbial residues (Gleixner et al. 1999; Gleixner et al. 2002; Godbold et al. 2006). Other potentially important fungal substances include melanin, hydrophobins, and in AM fungi, glomalin (Treseder and Allen 2000). The assumption that fungal cell walls (chitin) may be more resistant to degradation than plant cell walls (cellulose and lignin) is based on comparison of decomposition rates of whole tissues. The decomposition rate of EM root tips in the field in a study by Langley et al. (2006) was $65 \%$ slower than non-mycorrhizal root tips despite having a lower $\mathrm{C}: \mathrm{N}$ ratio which would, in plant material, be expected to increase the decomposition rate. However, recent data question whether EM roots tips have slower rates of decomposition than non-mycorrhizal root tips (Koide et al. 2011), and the higher recalcitrance of chitin than lignin (Koide and Malcolm 2009). The higher recalcitrance of chitin than other fungal compounds has also been questioned (Fernandez and Koide 2012). Estimates of the rates of decomposition of EMM are few (Wilkinson et al. 2011; Fernandez and Koide 2012). Söderström (1979) showed that only 2-4\% of hyphae isolated from a $P$. sylvestris forest were metabolically active, suggesting that the degradation of 
inactive hyphae is slow. However, EM mycelium grown in the laboratory have been shown to decompose within several weeks (Fernandez and Koide 2012), with a relationship between the C:N of the mycelium and rates of decomposition (Koide and Malcolm 2009). But in contrast, Wilkinson et al. (2011) could find no relationship between the efflux of $\mathrm{CO}_{2}$ of decomposing hyphal material and the $\mathrm{C}: \mathrm{N}$ ratio of the added necromass. They did, however, find that $\mathrm{CO}_{2}$ efflux was dependent on the species richness of the necromass added. Clearly our current understanding of decomposition of fungal tissues is poor. A recent analysis (Schmidt et al. 2011) has questioned the importance of both composition and chemical recalcitrance of litter in the formation of SOM. These authors suggest that rather the persistence of organic matter is due to complex interactions with the soil environment such as sorption onto clay minerals and isolation in aggregates. Thus close contact of the fine hyphae of the EMM with soil mineral surfaces could explain the apparent persistence of mycorrhizal inputs in some forest soils but not in all. For example this mechanism is not applicable in most forest soils in Sweden which typically have very low clay content, without aggregate formation in the mineral soil and an organic layer on top.

We suggest that the decomposition of EMM could, in principle, follow three initial pathways: firstly, by autolysis, where by much of the hyphal material may be reused, secondly, through the activity of saprotrophic fungi and bacteria, and thirdly by grazing soil animals (Fig. 2). The relative importance of these mechanisms is unknown. Physical disturbances that disrupt the mycelium contact with the $\mathrm{C}$ supply of the host can cause rapid growth of saprotrophic fungi that use the dying mycorrhizal mycelium as a substrate (Lindahl et al. 2010). Such functional shifts in fungal communities, induced by disturbance, may be highly important for the nutrient release from EMM mycelia in boreal forests (Lindahl et al. 2010). The residual materials produced in the above three principal pathways may have different quality. In the first two cases, i.e. internal cycling (autolysis) or saprotrophic microorganisms, the residues are probably $\mathrm{N}$ poor and further decomposition may be relatively slow. Grazing, on the other hand, could leave a residue that is fragmented and relatively nutrient rich making further decomposition faster. Not all animals that feed on mycelium are grazers; Protura, one of the few groups of microarthropods that might be specialized on EM fungi, seem to have adapted to suck on hyphae (Pass and Szucsich 2011). Whether they suck out a minor part of the cytoplasm and leave living hyphae behind, or if they leave dead membranes is unknown. Currently, we can say no more than that microbial precursors appear to be very important in formation of SOM, and that the nature of these precursors and the pathways involved are still inadequately investigated.

\section{Heterotrophic activity}

The role of EM fungi in the decomposition of organic matter is currently a subject of much debate. Laboratory experiments have shown that many ericoid and EM fungi can decompose complex organic compounds (Read and Perez-Moreno 2003) and culture studies showed that EM can mineralize cellulose and lignin, but typically only at one tenth the rate of saprotrophic fungi (Trojanowski et al. 1984).

Several recent studies have tried to identify the factors triggering saprotrophy in EM fungi, and to assess its ecological significance (Courty et al. 2007; Cullings et al. 2008; Talbot et al. 2008; Cullings and Courty 2009). They hypothesise that saprotrophic $\mathrm{C}$ acquisition by EM fungi may be an alternative strategy: (1) during periods with low photosynthate supply from the host, (2) during periods of high photosynthate supply from the host, but when a supplementary resource for massive mycelial production is required, or (3) during decomposition of dying tree roots (Talbot et al. 2008; Baldrian 2009). However, there is presently little evidence for any of these hypotheses. In one of the few field studies testing the saprotrophic activity of EM fungi, addition of ${ }^{14} \mathrm{C}$-labelled litter to an oak forest floor showed that the EM fungi did not utilize the litter $\mathrm{C}$ and were totally dependent on host C (Treseder et al. 2006). While generalizations are impossible due to the missing experimental data, the ecological relevance of saprotrophic behaviour of EM fungi should be placed in the context of the large sustained supply of $\mathrm{C}$ derived from the autotrophic plant.

While the importance of the saprotrophic capacity of EM fungi to the C cycle is unknown, there is good evidence for their involvement in degrading $\mathrm{N}$ and $\mathrm{P}$ containing organic compounds. For instance, protease and chitinase production in EM fungi has 


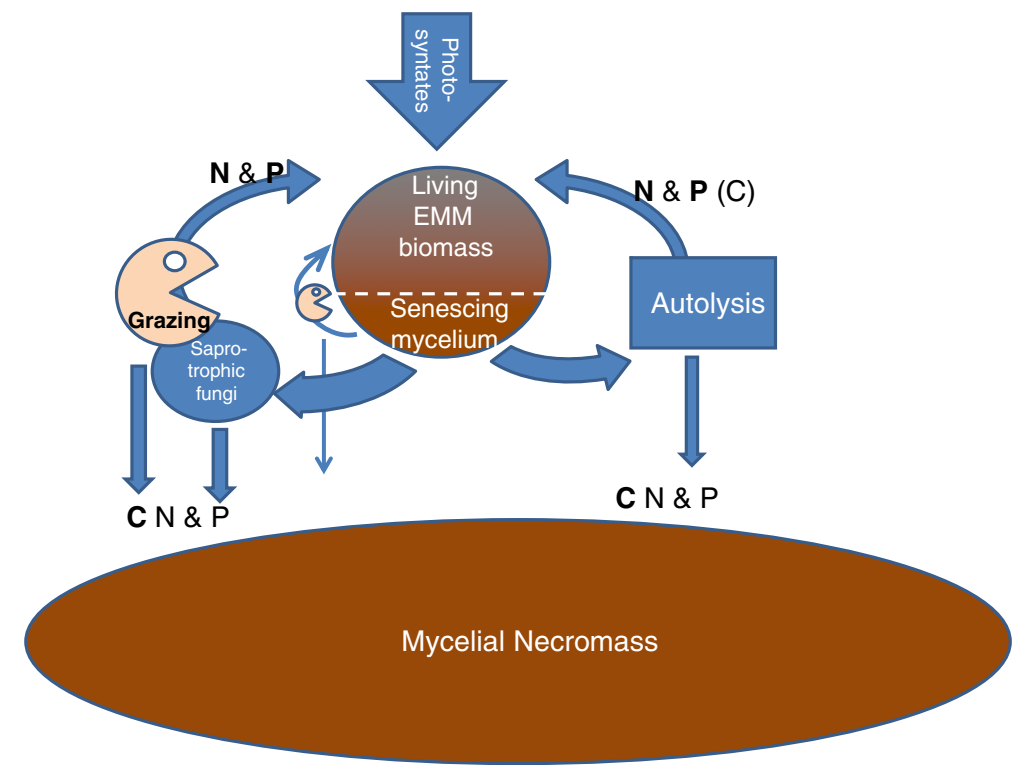

Fig. 2 Simplified scheme showing the different routes for turnover of extramatrical mycelium (EMM). Carbon for growth of the fungal biomass is supplied by plant photosynthates. The fungus is present as living hyphae (living EMM), senescing mycelium and mycelial necromass. The decomposition of the EMM could in principle follow three initial pathways: firstly, by autolysis, where by much of the $\mathrm{N}$ and $\mathrm{P}$ may be reused, secondly, through the activity of saprotrophic fungi and bacteria, and thirdly by a direct

been reported in several species (Hodge et al. 1995; Lindahl and Taylor 2004; Nygren et al. 2007), which will release amino sugars and amino acids from the degradation of chitin or polypeptides. The genome of $L$. bicolor contains $>100$ putative extracellular proteases and several chitinases and testifies to the ability to use a variety of $\mathrm{N}$-containing compounds (Martin and Selosse 2008) but the ability to use proteins and peptides varies greatly among EM fungi (Abuzinadah and Read 1986). The acquisition of organic $\mathrm{P}$ by EM fungi is mediated by the widespread activity of surface-bound phosphatases (Alvarez et al. 2006), although these activities appear to be largely species-dependent (Plassard et al. 2011).

Ectomycorrhizal fungi can also affect decomposition indirectly. Litter decomposition is less in plots with mycorrhizal roots than in plots without these roots (Gadgil and Gadgil 1975; Berg and Lindberg 1980). This so called 'Gadgil effect' is suggested to be caused by the efficient uptake of $\mathrm{N}$ and $\mathrm{P}$ by EM fungi reducing the availability of these nutrients for other microorganisms. Such a nutrient limitation may grazing by soil animals. The relative importance of these pathways is unknown but probably of great importance for the further decomposition of the materials. In this figure the direct grazing of the EMM is smaller than grazing of saprotrophic microorganisms, since this is suggested by recent studies (see section on grazing of mycelium) and the necromass is much larger than the standing biomass

be strengthened further by the immobilisation of $\mathrm{N}$ and $\mathrm{P}$ into a large biomass and possibly necromass of EMM (see above). Indeed, molecular methods show that forests dominated by EM trees have low abundance of bacteria (de Boer et al. 2005) and saprotrophic fungi that are primarily found in the surface litter (Lindahl et al. 2007). An alternative explanation of the 'Gadgil effect' is that water uptake by mycorrhizal roots and EMM reduce the soil water content causing a water limitation of decomposition (Koide and $\mathrm{Wu}$ 2003). The opposite effect, a stimulation of decomposition as a result of water uptake by mycorrhizal roots and EMM was found in soils with high groundwater levels (Jaatinen et al. 2008). The presence of EM hyphae can theoretically increase microbial decomposition of complex organic compounds by priming the co-metabolism of recalcitrant substrates by saprotrophic microorganisms, e.g. by the production of low molecular mass organic acids like oxalate (Kuzyakov et al. 2000; Fontaine et al. 2003) or specifically affect (inhibit) the activity of certain groups of decomposers by antibiosis (Tsantrizos et al. 1991; Frey-Klett et al. 2005). Because these indirect and 
direct effects of EM fungi on decomposition may act simultaneously, the net effect is difficult to calculate.

\section{Importance for soil $\mathrm{CO}_{2}$ fluxes and Dissolved Organic Carbon (DOC)}

Soil $\mathrm{CO}_{2}$ and dissolved organic carbon (DOC) efflux are the major pathways for $\mathrm{C}$ loss from soils. Partitioning of soil $\mathrm{CO}_{2}$ efflux into autotrophic respiration (from roots, mycorrhizal fungi and rhizosphere organisms, driven by photosynthates) and heterotrophic respiration from decomposition of SOM is recognized as critical for further improvement of models of ecosystem $\mathrm{C}$ budgets (Hughes et al. 2008; Chapin et al. 2009). Among the autotrophic components, mycorrhizal roots often exhibit higher specific respiration rates than non-mycorrhizal roots (Colpaert et al. 1996; De Grandcourt et al. 2004). This has been ascribed to higher construction costs that lead to a higher growth respiration coefficient and cost of nutrient absorption. The maintenance cost per unit biomass is indeed higher for hyphae than for roots (Fitter 1991).

While recent studies have documented the substantial amount of $\mathrm{C}$ translocated to the production of EMM, the contribution of the EMM to the soil $\mathrm{CO}_{2}$ efflux has rarely been studied under field conditions. This has been estimated using in-growth cores partly or wholly covered by fine mesh of different size, allowing or restricting the EMM growth into the core. Thus, it was estimated that the EMM contributed up to $60 \%$ of the autotrophic soil $\mathrm{CO}_{2}$ efflux and $25 \%$ of the total soil $\mathrm{CO}_{2}$ efflux in a Pinus contorta forest (Heinemeyer et al. 2007). A four-year study in an oak forest, attributed $18 \%$ of the annual soil $\mathrm{CO}_{2}$ efflux to EMM respiration (Heinemeyer et al. 2011), also showing the large seasonal and annual variability of the EMM contribution that may explain diverging findings; Moyano et al. (2008) reported lower contributions of EMM to the total soil $\mathrm{CO}_{2}$ efflux ( $8 \%$ in a spruce forest and only $3 \%$ in a beech forest).

Dissolved organic $\mathrm{C}$ in forest soils is a complex mixture; most is humic substances and a small proportion, often $<10 \%$, is compounds such as organic acids, amino acids, sugars and phenols (Kalbitz et al. 2000; Jones et al. 2004). The processes leading to its formation are still poorly understood and the contribution of roots and especially of EMM has only recently been addressed. The amount of water extractable organic $\mathrm{C}$ in the mor layer of a Pinus sylvestris forest decreased by $45 \% 1$ month after tree girdling compared to the control (Högberg and Högberg 2002). This points to a direct link between assimilate transport to roots and soil solution chemistry (Giesler et al. 2007). Similarly, the water extractable organic $\mathrm{C}$ was several times higher in mycelial mats than in soils outside mats (Griffiths et al. 1994) and in the mineral soil, oxalate concentration was 40 times higher in mats than in nonmat soil (Kluber et al. 2010), suggesting a large contribution of EMM to DOC production. In a laboratory experiment, the DOC produced by $P$. sylvestris seedlings with EM was $50 \%$ larger than the controls without EM (Johansson et al. 2009).

Both laboratory and field studies confirm the potential of EM to contribute to DOC in forest soil solutions, although there is a need for more detailed investigations which can be extrapolated to field conditions.

\section{Conclusion and future research}

Until a decade ago our knowledge about EMM production and its importance in $\mathrm{C}$ cycling was mainly based on laboratory experiments. Recent research using in-growth cores and mesh bags has demonstrated that the production of EMM is up to several hundreds of kilograms per ha per year in forests ecosystems, but the production seems to vary greatly between different forests and between years. We conclude that much of the recorded variation in EMM production can be explained by variations in the availability of $\mathrm{C}$ and other factors, such as $\mathrm{N}$ and $\mathrm{P}$ availability, may act mainly indirectly via the plant. Whether a change in EMM production is preceded by a change in the EM community is unknown, but perturbations that decrease the $\mathrm{C}$ availability seem to favour contact and smooth exploration types.

The EMM may not be an easily available food source for the decomposer community. Relatively few species of soil animals exhibit feeding preferences towards EM fungi and it is possible that animal grazing of saprotrophs is quantitatively more important than that of EM fungi, but this is an open area of research.

The lack of data on mycelial turnover rates is an obstacle to development of models of forest $\mathrm{C}$ cycling. 
We suggest that the slowest turnover rates of the total EMM are to be found in forests where long distance types are common in the fungal community. In such forests, both the standing EMM biomass as well as its $\mathrm{N}$ and $\mathrm{P}$ retention capacity may be large.

The classification of EM taxa into exploration groups based on morphological growth characteristics may be one way to describe the complex EM communities from a functional perspective. However, the ecological role is poorly known for many of the fungal taxa in a soil sample, and future research aiming at better characterization of these taxa is needed.

We hypothesise that the turnover of EM hyphae is more rapid in organic materials than in the mineral soil, which is motivated by the different functions the mycelium probably has in the two substrates. These two functions might be equally important as indicated from the few studies reporting EMM production rates also in the mineral soil. But this topic needs further studies.

Table 2 Critical questions for future research on the extramatrical mycelium (EMM) of ectomycorrhizal (EM) fungi

Question Comment

Are there geographical and/or tree species differences in EMM production, standing biomass and turnover?

How much of the variation in this respect is explained by variations in the EM community?

How much of the variation in this respect is explained by variations in the $\mathrm{C}: \mathrm{N}: \mathrm{P}$ stoichiometry?

Why is not increased $\mathrm{C}$ availability, by elevated $\mathrm{CO}_{2}$ causing an increase in the occurrence of long distance types?

Are there soil depth differences in mycelium production, standing biomass and turnover?

Ditto for substrate differences?

How large proportion of the production and standing biomass is rhizomorphs?

How large are the seasonal and between year variation in production and standing biomass?

Is the EM fungal versus saprotroph niche separation as found in a boreal forest (dominance of EM in the organic layer and mineral soil and saprotrophs in the litter) stable or has the two fungal groups different seasonal dynamics?

Is this niche separation the rule also in other forest ecosystems?

How fast is the decomposition of the mycelium?

How important are soil animals for the turnover of EMM?

How important are mammals for the EMM standing biomass and turnover of EMM?

Is EMM an important precursor for stable soil organic matter?

What is the relation between the biomass of EMM, environmental factors and the production of $\mathrm{CO}_{2}$ and DOC?
Much of the current knowledge comes from Picea abies and Scandinavia.

There are likely to be large differences between different exploration types but also within a single type.

Long term factorial fertilizer experiments are needed perhaps combined with defoliation experiments.

Perturbations that decrease the $\mathrm{C}$ availability for EMM growth seems to make contact and smooth exploration types more competitive than long distance types. Why not the opposite?

Most studies have focussed on the upper organic layer.

We need to test our hypothesis that mycelium turnover is slower in mineral soil than in organic layers. A difference in turnover is motivated by the different possible functions of the EMM in the two substrates.

We know of only one laboratory study. This is very important to know for C-turnover models.

We need studies with higher time resolution, one harvest of ingrowth bags per year is not enough.

Only one study at one time of the year so far.

In many broad leaved forests, the soil mixing by earthworms may make this depth separation of fungal functional groups less clear, but this needs to be studied.

There are probably large species differences. Mycelium grown in pure culture may differ significantly from that of a natural mycelium.

The picture we get from the few field studies is that the grazing of EMM may be limited but that conclusion is based on few studies. In many broad leaved forests the disturbance from earthworms may cause the mycelium to turnover more rapidly than in coniferous forests.

Selective grazing above as well as below ground may have great importance, e.g. the rooting of wild boar can be important.

There is some evidence supporting this but much more work is needed on this tricky question!

So far, no study has analysed $\mathrm{CO}_{2}$ efflux in combination with EMM biomass. 
Although the number of papers on EMM in forest soils has increased dramatically over the last decade, there are still very big gaps in our knowledge in most of the topics brought up in this review. As a guide for future research, the most important of these gaps are formulated as questions in Table 2. The EMM of EM fungi has several important roles in ecosystems. In this paper we have focused on its role in the C-cycle. There is increasing evidence that residues of EM fungi play a major role in the formation of stable $\mathrm{N}$ and $\mathrm{C}$ in $\mathrm{SOM}$, calling for a greater inclusion of EM inputs into models of soil $\mathrm{C}$ stores in forests.

Acknowledgments We thank Thomas W. Kuyper for fruitful comments on the manuscript. We also thank COST (European Cooperation in Science and Technology) for financial and coordinative support to the Cost Action FP0803: Belowground carbon turnover in European forests.

Open Access This article is distributed under the terms of the Creative Commons Attribution License which permits any use, distribution, and reproduction in any medium, provided the original author(s) and the source are credited.

\section{References}

Abuzinadah RA, Read DJ (1986) The role of proteins in the nitrogen nutrition of ectomycorrhizal plants. I. Utilization of proteins and peptides by ectomycorrhizal fungi. New Phytol 103:481-493

Agerer R (2001) Exploration types of ectomycorrhizae. A proposal to classify ectomycorrhizal mycelial systems according to their patterns of differentiation and putative ecological importance. Mycorrhiza 11:107-114

Agerer R, Rambold G (2004-2011) [first posted on 2004-06-01; most recent update: 2011-01-10]. DEEMY - An Information System for Characterization and Determination of Ectomycorrhizae. www.deemy.de - München, Germany

Alberton O, Kuyper TW (2009) Ectomycorrhizal fungi associated with Pinus sylvestris seedlings respond differently to increased carbon and nitrogen availability: implications for ecosystem responses to global change. Glob Change Biol 15:166-175

Alberton O, Kuyper TW, Gorissen A (2005) Taking mycocentrism seriously: mycorrhizal fungal and plant responses to elevated $\mathrm{CO}_{2}$. New Phytol 167:859-868

Allen MF (2007) Mycorrhizal Fungi: highways for water and nutrients in arid soils. Vadose Zone J 6:291-297

Alvarez M, Gieseke A, Godoy R, Hartel S (2006) Surface-bound phosphatase activity in ectomycorrhizal fungi: a comparative study between a colorimetric and a microscope-based method. Biol Fertil Soils 42:561-568

Arnebrant K (1994) Nitrogen amendments reduce the growth of ectramatrical mycelium. Mycorrhiza 5:7-15

Bååth E, Nilsson LO, Göransson H, Wallander H (2004) Can the extent of degradation of soil fungal mycelium during soil incubation be used to estimate ectomycorrhizal biomass in soil? Soil Biol Biochem 36:2105-2109

Bakker MR, Jolicoeur E, Trichet P, Augusto L, Plassard C, Guinberteau J, Loustau D (2009) Adaptation of fine roots to annual fertilization and irrigation in a 13-year-old Pinus pinaster stand. Tree Physiol 29:229-238

Baldrian P (2009) Ectomycorrhizal fungi and their enzymes in soils: is there enough evidence for their role as facultative soil saprotrophs? Oecologia 161:657-660

Bending GD, Read DJ (1995) The structure and function of the vegetative mycelium of ectomycorrhizal plants V. Foraging behaviour and translocation of nutrients from exploited litter. New Phytol 130:401-409

Bengtsson G, Erlandsson A, Rundgren S (1988) Fungal odour attracts soil Collembola. Soil Biol Biochem 20:25-30

Bengtsson G, Hedlund K, Rundgren S (1991) Selective odor perception in the soil Collembola Onychiurus armatus. J Chem Ecol 17:2113-2125

Berg B, Lindberg T (1980) Is litter decomposition retarded in the presence of mycorrhizal roots in forest soil? Swedish Coniferous Forest Project, Department of Ecology and Environmental Research, Swedish University of Agricultural Sciences. Internal Rep 95:10 pp

Berggren Kleja D, Svensson M, Majdi H, Jansson P-E, Langvall O, Bergkvist B, Johansson MB, Weslien P, Truusb L, Lindroth A, Ågren GI (2008) Pools and fluxes of carbon in three Norway spruce ecosystems along a climatic gradient in Sweden. Biogeochem 89:7-25

Bhupinderpal-Singh NA, Ottosson-Löfvenius M, Högberg MN, Mellander P-E, Högberg P (2003) Tree root and soil heterotrophic respiration as revealed by girdling of boreal Scots pine forest: extending observations beyond the first year. Plant Cell Environ 26:1287-1296

Bidartondo MI, Ek H, Wallander H, Söderström B (2001) Do nutrient additions alter carbon sink strength of ectomycorrhizal fungi? New Phytol 151:543-550

Böllmann J, Elmer M, Wöllecke J, Raidl S, Hüttl RF (2010) Defensive strategies of soil fungi to prevent grazing by Folsomia candida (Collembola). Pedobiol 53:107-114

Boström B, Comstedt D, Ekblad A (2007) Isotope fractionation and ${ }^{13} \mathrm{C}$ enrichment in soil profiles during the decomposition of soil organic matter. Oecologia 153:89-98

Brunner I, Bakker M, Björk R, Hirano Y, Lukac M, Aranda X, Børja I, Eldhuset T, Helmisaari H, Jourdan C, Konôpka B, López B, Miguel Pérez C, Persson H, Ostonen I (2012) Fine-root turnover rates of European forests revisited: an analysis of data from sequential coring and ingrowth cores. Plant Soil. doi:10.1007/s11104-012-1313-5

Cairney JWG (2011) Ectomycorrhizal fungi: the symbiotic route to the root for phosphorus in forest soils. Plant Soil 344:51-71

Cairney JWG (2012) Extramatrical mycelia of ectomycorrhizal fungi as moderators of carbon dynamics in forest soil. Soil Biol Biochem 47:198-208

Caldwell MM, Dawson TE, Richards JH (1998) Hydraulic lift: consequences of water efflux from the roots of plants. Oecologia 113:151-161

Chapin FS III, McFarland J, McGuire AD, Euskirchen ES, Ruess RW, Kielland K (2009) The changing global carbon cycle: linking plant-soil carbon dynamics to global consequences. J Ecol 97:840-850 
Clemmensen KE, Michelsen A, Jonasson S, Shaver GR (2006) Increased ectomycorrhizal fungal abundance after longterm fertilization and warming of two arctic tundra ecosystems. New Phytol 171:391-404

Colpaert JV, van Laere A, van Assche JA (1996) Carbon and nitrogen allocation in ectomycorrhizal and non-mycorrhizal Pinus sylvestris L. seedlings. Tree Physiol 16:787-793

Courty P-E, Bréda N, Garbaye J (2007) Relation between oak tree phenology and the secretion of organic matter degrading enzymes by Lactarius quietus ectomycorrhizas before and during bud break. Soil Biol Biochem 39:1655-1663

Courty P-E, Buée M, Diedhiou AG, Frey-Klett P, Le Tacon F, Rineau F, Turpault M-P, Uroz S, Garbaye J (2010) The role of ectomycorrhizal communities in forest ecosystem processes: New perspectives and emerging concepts. Soil Biol Biochem 42:679-698

Coutts MP, Nicholl BC (1990) Growth and survival of shoots, roots and mycorrhizal mycelium in clonal Sitka spruce during the first growing season after planting. Can J For Res 20:861-868

Cromack K Jr, Sollins P, Grausttein WC, Speidel K, Todd AW, Spycher G, Li CY, Todd RL (1979) Calcium oxalate accumulation and soil weathering in mats of the hypogeous fungus Hysterangium crassum. Soil Biol Biochem 11:463-468

Cullings K, Courty P-E (2009) Saprotrophic capabilities as functional traits to study functional diversity and resilience of ectomycorrhizal community. Oecologia 161:661-664

Cullings K, Vogler DR, Parker VT, Makhija S (2001) Defoliation effects on the community of a mixed Pinus contorta/Picea engelmannii stand in Yellowstone Park. Oecologia 127:533539

Cullings K, Ishkhanova G, Henson J (2008) Defoliation effects on enzyme activities of the ectomycorrhizal fungus Suillus granulatus in a Pinus contorta (lodgepole pine) stand in Yellowstone National Park. Oecologia 158:77-83

Dahlberg A (2001) Community ecology of ectomycorrhizal fungi: an advancing interdisciplinary field. New Phytol 150:555-562

Dahlberg A, Stenlid J (1994) Size, distribution and biomass of genets in populations of Suillus bovinus (L.: Fr.) Roussel revealed by somatic incompatibility. New Phytol 128:225-234

de Boer W, Folman LB, Summerbell RC, Boddy L (2005) Living in a fungal world: impact of fungi on soil bacterial niche development. FEMS Microbiol Rev 29:795-811

De Grandcourt A, Epron D, Montpied P, Louisanna E, Béreau M, Garbaye J, Guehl J-M (2004) Contrasting responses to mycorrhizal inoculation and phosphorus availability in seedlings of two tropical rainforest tree species. New Phytol 161:865-875

Dickie IA, Xu W, Koide RT (2002) Vertical niche differentiation of ectomycorrhizal hyphae in soils as shown by T-RFLP analysis. New Phytol 156:527-535

Donnelly DP, Boddy L, Leake JR (2004) Development, persistence and regeneration of foraging ectomycorrhizal mycelial systems in soil microcosms. Mycorrhiza 14:37-45

Duddridge JA, Malibari A, Read DJ (1980) Structure and function of mycorrhizal rhizomorphs with special reference to their role in water transport. Nature 287:834-836

Ehleringer JR, Buchmann N, Flanagan LB (2000) Carbon isotope ratios in belowground carbon cycle processes. Ecol Appl 10:412-422
Ek H (1997) The influence of nitrogen fertilization on the carbon economy of Paxillus involutus in ectomycorrhizal association with Betula pendula. New Phytol 135:133-142

Ek H, Sjögren M, Arnebtant K, Söderström B (1994) Extramatrical mycelial growth, biomass allocation and nitrogen uptake in ectomycorrhizal systems in response to collembolan grazing. Appl Soil Ecol 1:155-169

Ekblad A, Näsholm T (1996) Determination of chitin in fungi and mycorrhizal roots by an improved HPLC analysis of glucosamine. Plant Soil 178:29-35

Ekblad A, Wallander H, Carlsson R, HussDanell K (1995) Fungal biomass in roots and extramatrical mycelium in relation to macronutrients and plant biomass of ectomycorrhizal Pinus sylvestris and Alnus incana. New Phytol 131:443-451

Ekblad A, Wallander H, Näsholm T (1998) Chitin and ergosterol combined to measure total and living fungal biomass in ectomycorrhizas. New Phytol 138:143-149

Epron D, Ngao J, Dannoura M, Bakker MR, Zeller B, Bazot S, Bosc A, Plain C, Lata JC, Priault P, Barthes L, Loustau D (2011) Seasonal variations of belowground carbon transfer assessed by in situ ${ }^{13} \mathrm{CO}_{2}$ pulse labelling of trees. Biogeosci Discuss 8:885-919

Fernandez CW, Koide RT (2012) The role of chitin in the decomposition of ectomycorrhizal fungal litter. Ecology 93:24-28

Finér L, Ohashi M, Noguchi K, Hirano Y (2011) Fine root production and turnover in forest ecosystems in relation to stand and environmental characteristics. For Ecol Manage 262:2008-2023

Finlay RD (2008) Ecological aspects of mycorrhizal symbiosis: with special emphasis on the functional diversity of interactions involving the extraradical mycelium. J Exp Bot 59:1115-1126

Finlay RD, Read DJ (1986) The structure and function of the vegetative mycelium of ectomycorrhizal plants. I. Translocation of ${ }^{14} \mathrm{C}$-labelled carbon between plants interconnected by a common mycelium. New Phytol 103:143-156

Finlay R, Söderström B (1992) Mycorrhiza and carbon flow to the soil. In: Allen MF (ed) Mycorrhizal functioning: an integrative plant-fungal process. Chapman and Hall, Routledge, pp 134-162

Fitter AH (1991) Costs and benefits of mycorrhizas: implications for functioning under natural conditions. Experientia 47:350-355

Fitter AH, Sanders IR (1992) Interactions with the soil fauna. In: Allen MF (ed) Mycorrhizal functioning: an integrative plant-fungal process. Chapman and Hall, Routledge, pp 333-354

Fontaine S, Mariotti A, Abbadie L (2003) The priming effect of organic matter: a question of microbial competition? Soil Biol Biochem 35:837-843

Fransson PMA, Taylor AFS, Finlay RD (2001) Elevated atmospheric $\mathrm{CO}_{2}$ alters root symbiont community structure in forest trees. New Phytol 152:431-442

Fransson PMA, Taylor AFS, Finlay RD (2005) Mycelial production, spread and root colonisation by ectomycorrhizal fungi Hebeloma crustuliniforme and Paxillus involutus under elevated atmospheric $\mathrm{CO}_{2}$. Mycorrhiza 15:25-31

Frey-Klett P, Chavatte M, Clausse ML, Courrier S, Le Roux C, Raaijmakers J, Martinotti MG, Pierrat JC, Garbaye J (2005) Ectomycorrhizal symbiosis affects functional 
diversity of rhizosphere fluorescent pseudomonads. New Phytol 165:317-328

Gadgil RL, Gadgil PD (1975) Suppression of litter decomposition by mycorrhizal roots of Pinus radiata. New Zealand J For Sci 5:33-41

Garcia MO, Ovasapyan T, Greas M, Treseder KK (2008) Mycorrhizal dynamics under elevated $\mathrm{CO}_{2}$ and nitrogen fertilization in a warm temperate forest. Plant Soil 303:301310

Gebauer G, Schulze ED (1991) Carbon and nitrogen isotope ratios in different compartments of a healthy and a declining Picea-abies forest in the Fichtelgebirge, Ne Bavaria. Oecologia 87:198-207

Gehring CA, Whitham TG (2002) Mycorrhizae-Herbivore interactions: population and community consequences. In: van der Heijden MGA, Sanders I (eds) Mycorrhizal ecology, ecological studies, Vol. 157. Springer, pp 295-320

Genney DR, Anderson IC, Alexander IJ (2006) Fine-scale distribution of pine ectomycorrhizas and their extramatrical mycelium. New Phytol 170:381-390

Giesler R, Högberg MN, Strobel BW, Richter A, Nordgren A, Högberg P (2007) Production of dissolved organic carbon and low-molecular weight organic acids in soil solution driven by recent tree photosynthate. Biogeochem 84:1-12

Gill RA, Jackson RB (2000) Global patterns of root turnover for terrestrial ecosystems. New Phytol 147:13-31

Gleixner G (2005) Stable isotope composition of soil organic matter. In: Flanagan LB, Ehleringer JR, Pataki DE (eds) Stable isotopes and biosphere-atmosphere interactions: processes and biological controls. Academic, London, pp 29-46

Gleixner G, Bol R, Balesdent J (1999) Molecular insight into soil carbon turnover. Rapid Commun Mass Spectrom 13:1278-1283

Gleixner G, Poirier N, Bol R, Balesdent J (2002) Molecular dynamics of organic matter in a cultivated soil. Org Geochem 33:357-366

Godbold DL, Berntson GM, Bazzaz FA (1997) Growth and mycorrhizal colonization of three North American tree species under elevated atmospheric $\mathrm{CO}_{2}$. New Phytol 137:433-440

Godbold DL, Hoosbeek MR, Lukac M, Cotrufo MF, Janssens IA, Ceulemans R, Polle A, Velthorst EJ, Scarascia-Mugnozza G, De Angelis P, Miglietta F, Peressotti A (2006) Mycorrhizal turnover as a dominant process for carbon input into soil organic matter. Plant Soil 281:15-24

Gorissen A, Kuyper TH (2000) Fungal species-specific responses of ectomycorrhizal Scots pine (Pinus sylvestris) to elevated $\left[\mathrm{CO}_{2}\right]$. New Phytol 146:163-168

Grebenc T, Kraigher H (2007) Changes in the community of ectomycorrhizal fungi and increased fine root number under adult beech trees chronically fumigated with double ambient ozone concentration. Plant Biol (Stuttg) 9:279-287

Griffiths RP, Baham JE, Caldwell BA (1994) Soil solution chemistry of ectomycorrhizal mats in forest soil. Soil Biol Biochem 26:331-337

Hagerberg D, Wallander H (2002) The impact of forest residue removal and wood ash amendment on the growth of the ectomycorrhizal external mycelium. FEMS Microbiol Ecol 39:139-146

Hagerberg D, Thelin G, Wallander H (2003) The production of ectomycorrhizal mycelium in forests: Relation between forest nutrient status and local mineral sources. Plant Soil 252:279-290

Harley JL (1989) The significance of mycorrhizal. Mycol Res 92:129-139

Heinemeyer A, Hartley IP, Evans SP, De la Fuente JAC, Ineson $\mathrm{P}$ (2007) Forest soil $\mathrm{CO}_{2}$ flux: uncovering the contribution and environmental responses of ectomycorrhizas. Glob Chang Biol 13:1786-1797

Heinemeyer A, Wilkinson M, Vargas R, Subke J-A, Casella E, Morison JIL, Ineson P (2011) Exploring the "overflow tap" theory: linking forest soil $\mathrm{CO}_{2}$ fluxes and individual mycorrhizosphere components to photosynthesis. Biogeosciences Discuss 8:3155-3201

Hendricks JJ, Mitchell RJ, Kuehn KA, Pecot SD, Sims SE (2006) Measuring external mycelia production of ectomycorrhizal fungi in the field: the soil matrix matters. New Phytol 171:179-186

Hobbie EA (2006) Carbon allocation to ectomycorrhizal fungi correlates with belowground allocation in culture studies. Ecology 87:563-569

Hobbie EA, Agerer R (2010) Nitrogen isotopes in ectomycorrhizal mushrooms correspond to belowground exploration types. Plant Soil 327:71-83

Hodge A, Fitter AH (2010) Substantial nitrogen acquisition by arbuscular mycorrhizal fungi from organic material has implications for $\mathrm{N}$ cycling. Proc Natl Acad Sci USA 107:13754-13759

Hodge A, Alexander IJ, Gooday GW (1995) Chitinolytic enzymes of pathogenic and ectomycorrhizal fungi. Mycol Res 99:935-941

Hodge A, Helgason T, Fitter AH (2010) Nutritional ecology of arbuscular mycorrhizal fungi. Fungal Ecol 3:267-273

Högberg MN, Högberg P (2002) Extramatrical ectomycorrhizal mycelium contributes one-third of microbial biomass and produces, together with associated roots, half the dissolved organic carbon in a forest soil. New Phytol 154:791-795

Högberg P, Högbom L, Schinkel H, Högberg M, Johannisson C, Wallmark H (1996) ${ }^{15} \mathrm{~N}$ abundance of surface soils, roots and mycorrhizas in profiles of European forest soils. Oecologia 108:207-214

Högberg P, Nordgren A, Buchmann N, Taylor AFS, Ekblad A, Högberg MN, Nyberg G, Ottosson-Löfvenius M, Read DJ (2001) Large-scale forest girdling shows that current photosynthesis drives soil respiration. Nature 411:789-792

Högberg MN, Bååth E, Nordgren A, Arnebrant K, Högberg P (2003) Contrasting effects of nitrogen availability on plant carbon supply to mycorrhizal fungi and saprotrophs - a hypothesis based on field observations in boreal forests. New Phytol 160:225-238

Högberg MN, Briones MJI, Keel SG, Metcalfe DB, Campbell C, Midwood AJ, Thornton B, Hurry V, Linder S, Näsholm T, Högberg P (2010) Quantification of effects of season and nitrogen supply on tree below-ground carbon transfer to ectomycorrhizal fungi and other soil organisms in a boreal pine forest. New Phytol 187:485-493

Högberg P, Johannisson C, Yarwood S, Callesen I, Näsholm T, Myrold DD, Högberg M (2011) Recovery of ectomycorrhiza after 'nitrogen saturation' of a conifer forest. New Phytol 189:515-525

Hopkin SP (1997) Biology of the Springtails: (Insecta: Collembola). Oxford Univ. Press, Oxford 
Hughes JK, Hodge A, Fitter AH, Atkin OK (2008) Mycorrhizal respiration: implications for global scaling relationships. Trends Plant Sci 13:583-588

Ingham ER, Griffiths RP, Cromack K, Entry JA (1991) Comparison of direct vs fumigation incubation microbial biomass estimates from ectomycorrhizal mat and non-mat soils. Soil Biol Biochem 23:465-471

Jaatinen K, Laiho R, Vuorenmaa A, del Castillo U, Minkkinen K, Pennanen T, Penttila T, Fritze H (2008) Responses of aerobic microbial communities and soil respiration to water-level drawdown in a northern boreal fen. Environ Microbiol 10:339-353

Jentschke G, Godbold DL, Brandes B (2001) Nitrogen limitation in mycorrhizal Norway spruce (Picea abies) seedlings induced mycelial foraging for ammonium: implications for $\mathrm{Ca}$ and $\mathrm{Mg}$ uptake. Plant Soil 234:109-117

Johansson EM, Fransson PM, Finlay RD, van Hees PA (2009) Quantitative analysis of soluble exudates produced by ectomycorrhizal roots as a response to ambient and elevated $\mathrm{CO}_{2}$. Soil Biol Biochem 41:1111-1116

Johnson NC (2010) Resource stoichiometry elucidates the structure and function of arbuscular mycorrhizas across scales. New Phytol 185:631-647

Johnson D, Leake JR, Ostle N, Ineson P, Read DJ (2002) In situ ${ }^{13} \mathrm{CO}_{2}$ pulse labelling of upland grassland demonstrates a rapid pathway of carbon flux from arbuscular mycorrhizal mycelia to the soil. New Phytol 153:327334

Johnson D, Krsek M, Wellington EMH, Stott AW, Cole L, Bardgett RD, Read DJ, Leake JR (2005) Soil invertebrates disrupt carbon flow through fungal networks. Science 309:1047

Jones DL, Hodge A, Kuzyakov Y (2004) Plant and mycorrhizal regulation of rhizodeposition. New Phytol 163:459-480

Jones DL, Nguyen C, Finlay RD (2009) Carbon flow in the rhizosphere: carbon trading at the soil-root interface. Plant Soil 321:5-33

Kalbitz K, Solinger S, Park J-H, Michalzik B, Matzner E (2000) Controls on the dynamics of dissolved organic matter in soils: A review. Soil Sci 165:277-304

Kalliokoski T, Pennanen T, Nygren P, Sievänen R, Helmisaari $\mathrm{H}-\mathrm{S}$ (2010) Belowground interspecific competition in mixed boreal forests: fine root and ectomycorrhiza characteristics along stand developmental stage and soil fertility gradients. Plant Soil 330:73-89

Kaneda S, Kaneko N (2004) The feeding preference of a collembolan (Folsomia candida Willem) on ectomycorrhiza (Pisolithus tinctorius (Pers.)) varies with mycelial growth condition and vitality. Appl Soil Ecol 27:1-5

Kårén O, Nylund J-E (1997) Effects of ammonium sulphate on the community structure and biomass of ectomycorrhizal fungi in a Norway spruce stand in southwestern Sweden. Can J Bot 75:1628-1642

Kasurinen A, Keinanen MM, Kaipainen S, Nilsson LO, Vapaavuori E, Kontro MH, Holopainen T (2005) Belowground responses of silver birch trees exposed to elevated $\mathrm{CO}_{2}$ and $\mathrm{O}_{3}$ levels during three growing seasons. Glob Chang Biol 11:1167-1179

Kimmins JP (2004) Forest Ecology, a foundation for sustainable forest management and environmental ethics in forestry. Prentice Hall, Upper Saddle River
Kjöller R (2006) Disproportionate abundance between ectomycorrhizal root tips and their associated mycelia. FEMS Microbiol Ecol 58:214-224

Klironomos JN, Hart MM (2001) Animal nitrogen swap for plant carbon. Nature 410:651-652

Kluber LA, Tinnesand KM, Caldwell BA, Dunhamd SM, Yarwood RR, Bottomley PJ, Myrold DD (2010) Ectomycorrhizal mats alter forest soil biogeochemistry. Soil Biol Biochem 42:1607-1613

Koide RT, Malcolm GM (2009) N concentration controls decomposition rates of different strains of ectomycorrhizal fungi. Fungal Ecol 2:197-202

Koide RT, Wu T (2003) Ectomycorrhizas and retarded decomposition in a Pinus resinosa plantation. New Phytol 158:401-407

Koide RT, Fernandez CW, Peoples MS (2011) Can ectomycorrhizal colonization of Pinus resinosa roots affect their decomposition? New Phytol 191:508-514

Korkama T, Fritze H, Pakkanen A, Pennanen T (2007) Interactions between extraradical ectomycorrhizal mycelia, microbes associated with the mycelia and growth rate of Norway spruce (Picea abies) clones. New Phytol 173:798807

Kraigher H, Grebenc T, Hanke DE (2008) Ozone stress and ectomycorrhizal root-shoot signalling. In: Varma A (ed) Mycorrhiza: state of the art, genetics and molecular biology, eco-function, biotechnology, eco-physiology, structure and systematic, 3rd edn. Springer, Berlin, pp 337-357

Krauss J, Funke W (1999) Extraordinary high density of Protura in a windfall area of young spruce stands. Pedobiol 43:44-46

Kuzyakov Y, Friedel JK, Stahr K (2000) Review of mechanisms and quantification of priming effects. Soil Biol Biochem 32:1485-1498

Landeweert R, Hoffland E, Finlay RD, Kuyper TW, van Breemen N (2001) Linking plants to rocks: ectomycorrhizal fungi mobilize nutrients from minerals. Trends Ecol Evol 16:248-254

Landeweert R, Leeflang P, Kuyper TW, Hoffland E, Rosling A, Wernars K, Smit E (2003) Molecular identification of ectomycorrhizal mycelium in soil horizons. Appl Environ Microbiol 69:327-333

Langley JA, Hungate BA (2003) Mycorrhizal controls on belowground litter quality. Ecology 84:2302-2312

Langley JA, Chapman SK, Hungate BA (2006) Ectomycorrhizal colonization slows root decomposition, the post-mortem fungal legacy. Ecol Lett 9:955-959

Last FT, Dighton J, Mason PA (1987) Successions of sheathing mycorrhizal fungi. Trends Ecol Evol 2:157-161

Lawrynowicz M, Falinski JB, Bober J (2006) Interactions among hypogeous fungi wild boars in the subcontinental pine forest. Biodivers Res Conserv 1-2:102-106

Leake JR, Donnelly DP, Saunders EM, Boddy L, Read DJ (2001) Rates and quantities of carbon flux to ectomycorrhizal mycelium following ${ }^{14} \mathrm{C}$ pulse labeling of Pinus sylvestris seedlings: effects of litter patches and interaction with a wood-decomposer fungus. Tree Physiol 21:71-82

Leake J, Johnson D, Donnelly D, Muckle G, Boddy L, Read D (2004) Networks of power and influence: the role of mycorrhizal mycelium in controlling plant communities and agroecosystem functioning. Can J Bot 82:1016-1045

Leake JR, Ostle NJ, Rangel-Castro JI, Johnson D (2006) Carbon fluxes from plants through soil organisms determined by 
field ${ }^{13} \mathrm{CO}_{2}$ pulse-labelling in an upland grassland. Appl Soil Ecol 33:152-175

Lilleskov EA, Bruns TD, Dawson TE, Camacho FJ (2009) Water sources and controls on water-loss rates of epigeous ectomycorrhizal fungal sporocarps during summer drought. New Phytol 182:483-494

Lindahl BD, Taylor AFS (2004) Occurrence of Nacetylhexosaminidase-encoding genes in ectomycorrhizal basidiomycetes. New Phytol 164:193-199

Lindahl BD, Ihrmark K, Boberg J, Trumbore SE, Högberg P, Stenlid J, Finlay RD (2007) Spatial separation of litter decomposition and mycorrhizal nitrogen uptake in a boreal forest. New Phytol 173:611-620

Lindahl BD, de Boer W, Finlay RD (2010) Disruption of root carbon transport into forest humus stimulates fungal opportunists at the expense of mycorrhizal fungi. ISME J 4:872881

Litton CM, Raich JW, Ryan MG (2007) Carbon allocation in forest ecosystems. Glob Chang Biol 13:2089-2109

Lussenhop J, Fogel R (1999) Seasonal change in phosphorus content of Pinus strobus - Cenococcum geophilum ectomycorrhizae. Mycologia 91:742-746

MacArthur RH, Pianka ER (1966) On optimal use of a patchy environment. Am Nat 100:603-609

Majdi H, Truus L, Johansson U, Nylund JE, Wallander H (2008) Effects of slash retention and wood ash addition on fine root biomass and production and ectomycorrhizal mycelium in a Norway spruce stand in SW Sweden. For Ecol Manage 255:2109-2117

Malmström A, Persson T (2011) Responses of Collembola and Protura to tree girdling - some support for ectomycorrhizal feeding. Soil Org 83:279-285

Markkola A, Kuikka K, Rautio P, Härmä E, Roitto M, Tuomi J (2004) Defoliation increases carbon limitation in ectomycorrhizal symbiosis of Betula pubescens. Oecologia 140:234-240

Martin F, Selosse MA (2008) The Laccaria genome: a symbiont blueprint decoded. New Phytol 180:296-310

Massei G, Genov PV (2004) The environmental impact of wild boar. Galemys 16:135-145

Meyer A, Grote R, Polle A, Butterbach-Bahl K (2010) Simulating mycorrhiza contribution to forest C- and N cycling-the MYCOFON model. Plant Soil 327:493-517

Moyano FE, Kutsch WL, Rebmann C (2008) Soil respiration fluxes in relation to photosynthetic activity in broad-leaf and needle-leaf forest stands. Agr For Meteorol 148:135-143

Nadelhoffer KJ (2000) The potential effects of nitrogen deposition on fine-root production in forest ecosystems. New Phytol 147:131-139

Näsholm T, Nordin A, Edfast A-B, Högberg P (1997) Identification of coniferous forests with incipient nitrogen saturation through analysis of arginine and nitrogen-15 abundance of trees. J Environ Qual 26:302-309

Nilsson LO, Wallander H (2003) The production of external mycelium by ectomycorrhizal fungi in a Norway spruce forest was reduced in response to nitrogen fertilization. New Phytol 158:409-416

Nilsson LO, Giesler R, Bååth E, Wallander H (2005) Growth and biomass of mycorrhizal mycelia in coniferous forests along short natural nutrient gradients. New Phytol 165:613-622
Nilsson LO, Bååth E, Falkengren-Grerup U, Wallander H (2007) Growth of ectomycorrhizal mycelia and composition of soil microbial communities in oak forest soils along a nitrogen deposition gradient. Oecologia 153:375-384

Nilsson LO, Wallander H, Gundersen P (2012) Changes in microbial activities and biomasses over a forest floor gradient in C-to-N ratio. Plant Soil 355:75-86

Nygren CMR, Edqvist J, Elfstrand M, Heller G, Taylor AFS (2007) Detection of extracellular protease activity in different species and genera of ectomycorrhizal fungi. Mycorrhiza 17:241-248

Nylund J-E, Wallander H (1992) Ergosterol analysis as a means of quantifying mycorrhizal biomass. In: Norris JR, Read DJ, Varma AK (eds) Methods in microbiology vol 24. Academic, London, pp 77-88

Parrent JL, Vilgalys R (2007) Biomass and compositional responses of ectomycorrhizal fungal hyphae to elevated $\mathrm{CO}_{2}$ and nitrogen fertilization. New Phytol 176:164-174

Parrent JL, Morris WF, Vilgalys R (2006) $\mathrm{CO}_{2}$-enrichment and nutrient availability alter ectomycorrhizal fungal communities. Ecology 87:2278-2287

Pass G, Szucsich NU (2011) 100 years of research on the Protura: many secrets still retained. Soil Organisms 83:309-334

Pastor J, Naiman RJ (1992) Selective foraging and ecosystem processes in boreal forests. Am Nat 139:690-705

Perez-Moreno J, Read DJ (2000) Mobilization and transfer of nutrients from litter to tree seedlings via the vegetative mycelium of ectomycorrhizal plants. New Phytol 145:301-309

Persson T (1989) Role of soil animals in C and N mineralisation. Plant Soil 115:241-245

Persson I-L, Danell K, Bergström R (2000) Disturbance by large herbivores in boreal forests with special reference to moose. Ann Zool Fenn 37:251-263

Plassard C, Louche J, Ali MA, Duchemin M, Legname E, Cloutier-Hurteau B (2011) Diversity in phosphorus mobilisation and uptake in ectomycorrhizal fungi. Ann For Sci 68:33-43

Potila H, Wallander H, Sarjala T (2009) Growth of ectomycorrhizal fungi in drained peatland forests with variable $\mathrm{P}$ and K availability. Plant Soil 316:139-150

Pritchard SG, Strand AE, McCormack ML, Davis MA, Oren R (2008) Mycorrhizal and rhizomorph dynamics in a loblolly pine forest during 5 years of free-air- $\mathrm{CO}_{2}$-enrichment. Glob Chang Biol 14:1-13

Querejeta JI, Egerton WLM, Allen MF (2003) Direct nocturnal water transfer from oaks to their mycorrhizal symbionts during severe soil drying. Oecologia 134:55-64

Querejeta JI, Egerton-Warbrton LM, Allen MF (2007) Hydraulic lift may buffer rhizosphere hyphae against the negative effects of severe soil drying in a California Oak savanna. Soil Biol Biochem 39:409-417

Read DJ (1992) The mycorrhizal mycelium. In: Allen MF (ed) Mycorrhizal functioning. Chapman and Hall, London, pp 102-133

Read DJ, Perez-Moreno J (2003) Mycorrhizas and nutrient cycling in ecosystems - a journey towards relevance? New Phytol 157:475-492

Remén C, Persson T, Finlay R, Ahlström K (2008) Responses of oribatid mites to tree girdling and nutrient addition in boreal coniferous forests. Soil Biol Biochem 40:2881-2890 
Remén C, Fransson P, Persson T (2010) Population responses of oribatids and enchytraeids to ectomycorrhizal and saprotrophic fungi in plant-soil microcosms. Soil Biol Biochem 42:978-985

Rillig MC, Mummey DL (2006) Mycorrhizas and soil structure. New Phytol 171:41-53

Rosling A (2009) Trees, mycorrhiza and minerals - field relevance of in vitro experiments. Geomicrobiol J 26:389-401

Rosling A, Landeweert R, Lindahl BD, Larsson K-H, Kuyper TW, Taylor AFS, Finlay RD (2003) Vertical distribution of ectomycorrhizal fungal taxa in a podzol soil profile. New Phytol 159:775-783

Rosling A, Lindahl BD, Finlay RD (2004) Carbon allocation to ectomycorrhizal roots and mycelium colonising different mineral substrates. New Phytol 162:795-802

Rousseau JVD, Sylvia DM, Fox AJ (1994) Contribution of ectomycorrhiza to the potential nutrient-absorbing surface of pine. New Phytol 128:639-644

Saikkonen K, Ahonen-Jonnarth U, Markkola AM, Helander M, Tuomi J, Roitto M, Ranta H (1999) Defoliation and mycorrhizal symbiosis: a functional balance between carbon sources and below-ground sinks. Ecol Lett 2:19-26

Saravesi K, Markkola AM, Rautio P, Roitto M, Tuomi J (2008) Defoliation causes parallel temporal responses in a host tree and its fungal symbionts. Oecologia 156:117-123

Schmalholz M, Hylander K (2009) Succession of bryophyte assemblages following clear-cut logging in boreal southerncentral Sweden - Does retrogressive succession occur? Can J For Res 39:1871-1880

Schmidt MWI, Torn MS, Abiven S, Dittmar T, Guggenberger G, Janssens IA, Kleber M, Kögel-Knabner I, Lehmann J, Manning DAC, Nannipieri P, Rasse DP, Weiner S, Trumbore SE (2011) Persistence of soil organic matter as an ecosystem property. Nature 478:49-56

Setälä H (1995) Growth of birch and pine seedlings in relation to grazing by soil fauna on ectomycorrhizal fungi. Ecology $76: 1844-1851$

Setälä H (2000) Reciprocal interactions between Scots pine and soil food web structure in the presence and absence of ectomycorrhiza. Oecologia 125:109-118

Setälä H, Kulmala P, Mikola J, Makkola AM (1999) Influence of ectomycorrhiza on the structrue of detrital food webs in pine rhizosphere. Oikos 87:113-122

Shaw PJA (1988) Aconsistent hierarchy in the fungal feeding preferences of the Collembola Onychiurus armatus. Pedobiol $31: 3-4$

Simard SW (2009) The foundational role of mycorrhizal networks in self-organization of interior Douglas-fir forests. For Ecol Manage 258:95-107

Sims SE, Hendricks JJ, Mitchell RJ, Kuehn KA, Pecot SD (2007) Nitrogen decreases and precipitation increases ectomycorrhizal extramatrical mycelia production in a longleaf pine forest. Mycorrhiza 17:299-309

Smith SE, Read DJ (2008) Mycorrhizal Symbiosis 3rd edn. Academic, London

Söderström B (1979) Seasonal fluctuations of active fungal biomass in horizons of a podzolized pine-forest soil in central Sweden. Soil Biol Biochem 11:149-154

Söderström B, Read DJ (1987) Respiratory activity of intact and excised ectomycorrhizal mycelial systems growing in unsterilized soil. Soil Biol Biochem 19:231-236
Spiteller P (2008) Chemical defence strategies of higher fungi. Chem Eur J 14:9100-9110

Stadler M, Sterner O (1998) Production of bioactive secondary metabolites in the fruit bodies of macrofungi as a response to injury. Phytochem 49:1013-1019

Steinman K, Siegwolf RTW, Saurer M, Körner C (2004) Carbon fluxes to the soil in a mature temperate forest assessed by $13 \mathrm{C}$ isotope tracing. Oecologia 141:489-501

Stenström E (1991) The effects of flooding on the formation of ectomycorrhizae in Pinus sylvestris seedlings. Plant Soil 131:247-250

Talbot JM, Allison SD, Treseder KK (2008) Decomposers in disguise: mycorrhizal fungi as regulators of soil $\mathrm{C}$ dynamics in ecosystems under global change. Funct Ecology 22:955-963

Tamm C-O (1991) Nitrogen in terrestrial ecosystems. Springer, Berlin

Taylor AFS, Alexander I (2005) The ectomycorrhizal symbiosis: life in the real world. Mycologist 19:102-112

Tedersoo L, Kõljalg U, Hallenberg N, Larsson K-H (2003) Fine scale distribution of ectomycorrhizal fungi and roots across substrate layers including coarse woody debris in a mixed forest. New Phytol 159:153-165

Thelin G, Sverdrup H, Holmqvist J, Rosengren U, Lindén M (2002) Assessment of nutrient sustainability in Norway spruce and mixed Norway spruce-oak stands at Jämjö. In: Svedrup H, Stjernquist I (eds) Developing principles for sustainable forestry in southern Sweden. Kluwer, Dordrecht, pp 337-354

Treseder KK (2004) A meta-analysis of mycorrhizal responses to nitrogen, phosphorus, and atmospheric $\mathrm{CO}_{2}$ in field studies. New Phytol 164:347-355

Treseder KK, Allen MF (2000) Mycorrhizal fungi have a potential role in soil carbon storage under elevated $\mathrm{CO}_{2}$ and nitrogen deposition. New Phytol 147:189-200

Treseder KK, Allen MF, Ruess RW, Pregitzer KS, Hendrick RL (2005) Lifespans of fungal rhizomorphs under nitrogen fertilization in a pinyon-juniper woodland. Plant Soil 270:249-255

Treseder KK, Torn MS, Masiello CA (2006) An ecosystemscale radiocarbon tracer to test use of litter carbon by ectomycorrhizal fungi. Soil Biol Biochem 38:1077-1082

Trojanowski J, Haider K, Hüttermann A (1984) Decomposition of ${ }^{14} \mathrm{C}$-labelled lignin, holocellulose and lignocellulose by mycorrhizal fungi. Archives Microbiol 139:202-206

Tsantrizos YS, Kope HH, Fortin JA, Ogilvie KK (1991) Antifungal antibiotics from Pisolithus tinctorius. Phytochem 30:11131118

Unestam T (1991) Water repellency, mat formation, and leaf stimulated growth of some ectomycorrhizal fungi. Mycorrhiza 1:13-20

Unestam T, Sun Y-P (1995) Extramatrical structures of hydrophobic and hydrophilic ectomycorrhizal fungi. Mycorrhiza 5:301-311

van der Heijden MGA, Klironomos JN, Ursic M, Moutoglis P, Streitwolf-Engel R, Boller T, Wiemken A, Sanders IR (1998) Mycorrhizal fungal diversity determines plant biodiversity, ecosystem variability and productivity. Nature 396:69-72

van Schöll L, Kuyper T, Smits M, Landeweert R, Hoffland E, Breemen N (2008) Rock-eating mycorrhizas: their role in plant nutrition and biogeochemical cycles. Plant Soil 303:35-47 
Vargas R, Allen MF (2008) Dynamics of fine root, fungal rhizomorphs, and soil respiration in a mixed temperate forest: integrating sensors and observations. Vadose Zone J 7:1055-1064

Wallander H (1995) A new hypothesis to explain allocation of dry matter between ectomycorrhizal fungi and pine seedlings. Plant Soil 168-169:243-248

Wallander H, Nylund J-E (1992) Effects of excess nitrogen and phosphorus starvation on the extramatrical mycelium of ectomycorrhizas of Pinus sylverstris L. New Phytol 120:495-503

Wallander H, Pallon J (2005) Temporal changes in the elemental composition of Rhizopogon rhizomorphs during colonization of patches with fresh organic matter or acid-washed sand. Mycologia 97:295-303

Wallander H, Thelin G (2008) The stimulating effect of apatite on ectomycorrhizal growth diminish after PK fertilization. Soil Biol Biochem 40:2517-2522

Wallander H, Nilsson LO, Hagerberg D, Bååth E (2001) Estimation of the biomass and production of external mycelium of ectomycorrhizal fungi in the field. New Phytol 151:753-760

Wallander H, Nilsson LO, Hagerberg D, Rosengren U (2003) Direct estimates of $\mathrm{C}: \mathrm{N}$ ratios of ectomycorrhizal mycelia collected from Norway spruce forest soils. Soil Biol Biochem 35:997-999

Wallander H, Göransson H, Rosengren U (2004) Production, standing biomass and natural abundance of ${ }^{15} \mathrm{~N}$ and ${ }^{13} \mathrm{C}$ in ectomycorrhizal mycelia collected at different soil depths in two forest types. Oecologia 139:89-97

Wallander H, Johansson U, Sterkenburg E, Brandström M, Lindahl B (2010) Production of ectomycorrhizal mycelium peaks during canopy closure in Norway spruce forests. New Phytol 187:1124-1134

Wallander H, Ekblad A, Bergh J (2011) Growth and carbon sequestration by ectomycorrhizal fungi in intensively fertilized Norway spruce forests. For Ecol Manage 262:999-1007

Wallander H, Ekblad A, Godbold DL, Johnson D, Bahr A, Baldrian P, Björk RG, Kieliszewska-Rokicka B, Kjøller R, Kraigher H, Plassard C, Rudawska M (2013) Evaluation of methods to estimate production, biomass and turnover of ectomycorrhizal mycelium in forests soils - A review. Soil Biol Biochem 57:1034-1042

Warren JM, Brooks JR, Meinzer FC, Eberhart JL (2008) Hydraulic redistribution of water from Pinus ponderosa trees to seedlings: evidence for an ectomycorrhizal pathway. New Phytol 178:382-394

Weigt RB, Raidl S, Verma R, Rodenkirchen H, Göttlein A, Agerer $R$ (2011) Effects of twice-ambient carbon dioxide and nitrogen amendment on biomass, nutrient contents and carbon costs of Norway spruce seedlings as influenced by mycorrhization with Piloderma croceum and Tomentellopsis submollis. Mycorrhiza 21:375-391

Wiklund K, Nilsson L-O, Jacobsson S (1995) Effect of irrigation, fertilization, and artificial drought on basidioma production in a Norway spruce stand. Can J Bot 73:200-208

Wilkinson A, Alexander IJ, Johnson D (2011) Species richness of ectomycorrhizal hyphal necromass stimulates soil $\mathrm{CO}_{2}$ efflux under laboratory conditions. Soil Biol Biochem 43:1355-1355

Wu T (2011) Can ectomycorrhizal fungi circumvent the nitrogen mineralization for plant nutrition in temperate forest ecosystems? Soil Biol Biochem 43:1109-1117 